\begin{tabular}{|l|l|l|}
\hline & $\begin{array}{l}\text { Proceedings of the } \\
\text { Informing Science }+\end{array}$ & $\begin{array}{l}\text { An Official Publication } \\
\text { of the Informing Science Institute } \\
\text { InformingScience.org }\end{array}$ \\
\hline
\end{tabular}

June 30 - July 4, 2019, Jerusalem, Israel

\title{
CORPORATE SUSTAINABILITY: THE IMPACT OF CORPORATE LEADERSHIP GENDER ON YEAR OVER YEAR Performance
}

Jennoa R. Graham

Georgia State University, J. Mack

jennoa.graham@gmail.com

Robinson College of Business, Atlanta, GA, USA

\begin{abstract}
Aim/Purpose Women continue to be underrepresented in corporate leadership positions in the global market. Research examining the impact of female leadership influence on corporate sustainability over time is limited. This paper contributes to the literature addressing leadership gender, corporate sustainability, and business ethics.
\end{abstract}

Background Previous literature suggests the long-term effectiveness of corporate sustainability improves when females are in corporate leadership positions because of gender differences in business strategy and ethical considerations influenced by social roles.

Methodology This quantitative study will examine the relationships between corporate leadership gender, financial performance, environmental performance, social performance, and governance performance over four years. A sample of 99 multinational and large corporations participating in the Corporate Sustainability Assessment (CSA) from 2014 to 2017, were selected from the S\&P 500 Dow Jones Sustainability North American Composite Index.

Contribution Examining CEO, C-Suite, and Board of Director gender influence on both financial and ESG constructs in a single study is unprecedented. This research also introduces a paradigm shift in defining and analyzing corporate sustainability constructs to create a holistic view for equal consideration of financial and nonfinancial performance.

Findings The evidence suggests the impact of female leaders on year-over-year sustainability is significantly greater than that of their male counterparts across several performance outcomes, industries, and time periods. Due to the small sample size, the effect is small; however, enough information is available to successfully test

Accepting Editor: Eli Cohen | Received: (date) | Revised: (date) | Accepted: (date).

Cite as: Graham, J. R. (2019). Corporate sustainability: The impact of corporate leadership gender on year over year performance. Proceedings of the Informing Science and Information Technology Education Conference, Jerusalem, Israel, pp. 149-183. Santa Rosa, CA: Informing Science Institute. https://doi.org/10.28945/4213

(CC BY-NC 4.0) This article is licensed to you under a Creative Commons Attribution-NonCommercial 4.0 International License. When you copy and redistribute this paper in full or in part, you need to provide proper attribution to it to ensure that others can later locate this work (and to ensure that others do not accuse you of plagiarism). You may (and we encourage you to) adapt, remix, transform, and build upon the material for any non-commercial purposes. This license does not permit you to use this material for commercial purposes. 
hypotheses with the proposed holistic approach.

Future Research Corporate sustainability as an area of competitive advantage for women leaders and more global studies focusing on female leadership and corporate sustainability performance over time is needed.

Keywords leadership gender, corporate sustainability, CSR, business ethics

\section{INTRODUCTION}

Corporate sustainability, also known as sustainable development, was defined in 1987 by the World Commission on Environment and Development (WCED, 1987) as the corporations' ability to meet business needs "without compromising the ability of future generations to meet their own needs" (p.43). Sustainability is a subset topic beneath the overarching principle corporate social responsibility (CSR). CSR is a business strategy designed to incorporate economic, legal, ethical, and philanthropic (social) activities into the vision of the business (Geva 2008; Müller \& Pfleger 2014). These activities are measured by performance outcomes to determine alignment with strategic vision over time (Elkington 1997; Gao 2008; Müller \& Pfleger 2014; Wu, He, \& Duan, 2013). As a subset topic of CSR, sustainability is the process of performing the analysis on a continuum and ensuring generational longevity.

The literature review shows that the interpretation and application of sustainability has changed over the years due to perception (Carroll, Lipartito, Post, \& Werhane, 2012; Shaw, Nemer, Vial, \& Garner 2012: Wang 2015), but the foundational concept remains unchanged. To build trust and brand equity in communities, corporations must interact responsibly with people and the environment to achieve generational longevity (Idowu \& Louche 2011); locally and globally. To achieve sustainability, corporate leadership must obtain a holistic understanding of the interconnection between society, economy, and ecology (Shaw et al., 2012, p. 40). Building trust by creating relationships in communities secures holistic understanding and increases brand equity. As primary leaders, CEOs are responsible for influencing the direction of the corporation and ultimately the quality of interactions with people and the environment (Elsaid 2014; Glick 2011).

Previous gender studies suggest there are differences between male and female leaders that impact business strategy and ethical considerations used to achieve sustainability (Boulouta 2012; (Boulouta, 2012; Glass, Cook, \& Ingersoll, 2016). The literature suggests that female corporate leaders are focused on building long-term relationships within the community while male corporate leaders are focused on short-term financial gains. The literature also suggests that female leaders demonstrate communal characteristics such as nurturing, caring, and sensitivity resulting in a positive influence on corporation performance, board of director effectiveness, and a sense of holistic wellbeing for stakeholders (Green, 1996; Mattis, 1993). Active community engagement supports the relationship building needed to build trust, brand equity, and a holistic understanding. A review of the literature suggests that female corporate leaders are more actively engaged than male competitors through nonprofit service (Hillman, Cannella, \& Harris, 2002; Singh, Terjesen, \& Vinnicombe, 2008) and philanthropy (Ibrahim \& Angelidis, 1994; Konadu, 2017).

A study conducted by Burke (1993), revealed that in Fortune 500 companies 20 percent of females in directorship positions had previous service experience in some type of social service organization; including foundations. Although evidential research suggests that female corporate leaders more engaged in the community, as of October 2016, the number of female CEOs representing Fortune 500 companies holds steady at the 4\% range since 2011 (Javidan, Bullough, \& Dibble, 2016). Aspiring female corporate leaders seeking to compete in a male dominated for profit global market may find opportunity through understanding sustainability and how decisions impact year over year effectiveness (Marshall \& Hopfl, 2007; Müller \& Pfleger 2014; Ribera 2010). 
Current research examining the impact of female leadership influence on corporate sustainability over time is limited. Prior leadership gender studies addressed CEO and board of director impact on financial performance (Feng, Wang, \& Kreuze, 2017; Ho, Li, Tam, \& Zhang, 2014; Jalbert, Jalbert, \& Furumo, 2013; Ribera, 2010; Roberts, 2017; Tay, 2019), overall corporation performance (Khan and Vieito 2013), and leadership characteristics (Hoffman 2013). The results of those studies acknowledge the need for more women in leadership positions and current legislation is taking steps to expedite the process.

As of September 5, 2018, the state of California enrolled a senate bill (SB-826, Corporations: board of directors), mandating more females in the board room (Jackson \& Atkins, 2018).):

This bill, no later than the close of the 2019 calendar year, would require a domestic general corporation or foreign corporation that is a publicly held corporation, as defined, whose principal executive offices, according to the corporation's SEC 10-K form, are located in California to have a minimum of one female, as defined, on its board of directors, as specified. No later than the close of the 2021 calendar year, the bill would increase that required minimum number to 2 female directors if the corporation has 5 directors or to 3 female directors if the corporation has 6 or more directors. (p. 2)

While prior research has provided insight to the benefits of female leadership in financial and operational performance, it is necessary to increase the amount of empirical evidence for sustainability. The current study examines the relationships of corporate leadership gender and corporate sustainability performance outcomes; financial and non-financial (ESG). Female leadership refers to women who hold the job title of any c-suite position (i.e. CEO, CFO, COO, etc.) within a corporation. The theoretical framework of the Upper Echelon Theory developed in 1984 by Donald C. Hambrick and Phillis A. Mason (Hambrick 2007) and Social Role Theory (Koenig \& Eagly, 2014) was used for empirical evidence.

The Upper Echelon Theory states organizational performance may be predicted partially by leadership perception of values. CEOs and executive leadership make decisions based on personal and professional experiences (demographic characteristics) influencing value creation, community welfare, and the actions producing corporate performance outcomes (Hambrick \& Mason, 1984; , Jeong \& Harrison 2017; Nielsen, 2009). Social Role Theory states societal beliefs define acceptable gender roles (gender stereotypes) and assign value through the characteristics of the accepted roles. A study by Eagly (1987) indicates if current gender based behavior is consistent with previously observed gender based behavior, then the behavior is more likely to be approved by the observer. As mentioned previously, communal behavior is expected and accepted of female leaders and is prevalent in the nonprofit service and philanthropy. Communal behavior crosses professional experience (Upper Echelon) and gender stereotypes (Social Role).

A sample of 99 multinational and large corporations were selected from the S\&P 500 Dow Jones Sustainability North American Composite Index. The index represents the "top 20\% of the largest 600 North American companies in the S\&P Global BMI based on long-term economic, environmental and social criteria" (S\&P Dow Jones, 2018). The exclusion of corporations outside the US eliminated insights gained from cultural differences another demographical influences. The data was retrieved from Bloomberg LP, a global provider of financial news and annual corporate sustainability results. Data reported through Bloomberg is contingent upon the completeness and timeliness of the originating source and was assumed to be complete as of July 7, 2018.

The hypotheses for research questions will examine corporate leadership impact in three levels; CEO, C-Suite, and Board of Directors moderated by the global industry classification standard (GICS). "GICS was developed in response to the global financial community's need for one complete, consistent set of global sector and industry definitions, thereby enabling asset owners, asset managers and investment research specialists to make seamless company, sector, and industry comparisons across countries, regions, and globally" (RobecoSam, 2016). Examining CEO, C-Suite, and Board of 
Director gender influence on both financial and ESG performance outcomes in a single study is unprecedented.

The research maintains four objectives for this study: 1) present a concise literature review on the history, purpose and value of sustainability as a reference source 2) provide meaningful contributions to previous studies on leadership gender, sustainability, and business ethics 3) introduce a paradigm shift in defining and analyzing sustainability constructs to create a holistic view for equal consideration of financial and nonfinancial performance 4) identify sustainability as an area of competitive advantage for women leaders and begin a new trend in global studies focusing on female leadership and sustainability performance over time.

\section{LITERATURE REVIEW}

The primary purpose of the research is to determine corporate leadership gender impact on year over year corporate sustainability performance outcomes; financial and non-financial (ESG). The literature review presents a concise depiction of the history, purpose and value of corporate sustainability. The journey begins with a closer look at the origin story of corporate social responsibility.

\section{CORPORATE SOCIAL RESPONSIBILITY}

Corporate social responsibility (CSR) is defined for the study as an overarching principle aligning strategic business activities with expectations of society to conduct a profitable yet ethically considerate business (Brusseau, 2017). Society expectations represent positive or negative perceptions of implemented business activities during a given period. Increasingly positive perceptions of a corporation over time will drive higher levels of society expectations (Poolthong \& Mandhachitara, 2009). The expectation of mutual benefit between society and the corporation is considered a contract.

Earlier definitions of CSR were more focused on managing the needs and perceptions of society and/or stakeholders with less consideration given to profit (Bendell, 2009; Carroll, 1979). During an analysis covering six decades, Rahman (2011) and Dahlsrud (2008) discovered historical definitions of CSR shifted according to the dynamics (needs) of social welfare and the environment during a given period. The time progression in Table 1 shows the definitions provided by prominent scholars evolving from a philanthropic doctrine to a long-term vision of resource sharing and conservation.

\section{Table 1. CSR Defined by Prominent Scholars}

\begin{tabular}{|c|c|c|}
\hline Name & Year & Definition \\
\hline Howard Bowen & 1953 & $\begin{array}{l}\text { The CEO has an obligation to pursue policies, decisions, and actions that meet desirable } \\
\text { society objectives and values. }\end{array}$ \\
\hline Morrell Heald & 1957 & The CEO has an obligation to implement humane and constructive social policies. \\
\hline Keith Davis & 1960 & $\begin{array}{l}\text { CEO decisions and actions must go beyond the corporation's direct economic or tech- } \\
\text { nical interest. }\end{array}$ \\
\hline William C. Frederick & 1960 & $\begin{array}{l}\text { Implementing an economic system that meets society expectations by employing busi- } \\
\text { ness activities that enhance total socio-economic welfare. }\end{array}$ \\
\hline Clarence Walton & 1967 & $\begin{array}{l}\text { The intimate relationship between corporations and society must be preserved in pur- } \\
\text { suits to achieve perspective goals. }\end{array}$ \\
\hline Milton Friedman & 1970 & Maximize profits without deception or fraud. \\
\hline Archie B. Carroll & 1979 & $\begin{array}{l}\text { The inclusion of society expectations into economic, legal, and ethical considerations at } \\
\text { a given point of time. }\end{array}$ \\
\hline Thomas M. Jones & 1980 & $\begin{array}{l}\text { Corporations are obligated to constituent groups beyond traditional and societal groups } \\
\text { (i.e., national and global). }\end{array}$ \\
\hline
\end{tabular}


CSR was born from early 19th Century American ideals of philanthropy and fraternity reinforced by Christian views of Humanitarianism (Heald 1970). Christianity provided the American foundation of virtues and values needed to create a sense of common good for society. In a time of industrial revolution, corporations created a sense of common good for local communities by focusing on internal business operations such as employee welfare, labor conditions, and compensation resulting in increased productivity and profits (Brusseau, 2017; Crane, McWilliams, Matten, Moon, \& Siegel, 2008; Heald, 1970; Kotler \& Lee, 2005).

By the late 1800s and into the early-1900s community welfare and social programs were launched to fuel the philanthropic fire sweeping the country. Hospital clinics, educational institution endowments, neighborhood recreation (YMCA), and whole self-contained communities (The Pullman Experiment) were projects heavily influenced by society's perceptions of corporations (Crane et al., 2008). Bold social initiatives led to the Community Chest Movement, an early form of CSR where corporations became regularly educated on social problems and the agencies addressing community concerns (p. 22-23).

As corporations became educated on social issues, corporate leadership became more aware and connected with the community; paving the way for root cause analysis of social distress, and increased the corporation's local footprint (Heald, 1970). The corporation's community engagement shifted from a reactive position of donating time and resources to a proactive position for prevention and problem solving. As more resources were allocated to new initiatives, corporate leadership determined an urgent need to find ways of balancing society expectations with profitability goals (Elkington 1997, Gao 2008). The search for balance provided the foundation for the Triple Bottom Line (TBL) Theory.

TBL Theory, the first primary theory of CSR, states corporations must create value for long-term investors by being profitable, socially conscious, and environmentally protective (Hammer, 2015; Jeurissen, 2000). Practical actions are developed according to three performance constructs: financial, environmental and social (Elkington 1997, Gao 2008). Scholars such as Friedman (1970) and Arrow (1985) critique the philanthropic foundations of CSR and support only strategies focused on maximizing profits and giving in to shareholder desires. The scholarly research indicates the CEO is a representing agent of the corporation and CSR initiatives should not impede core business goals (profits).

Stakeholder Theory, the second primary theory of CSR, interprets the moral/philosophical guidelines for practical actions in corporation operations (Donaldson \& Preston 1995). Practical actions are developed and measured according to corporate goals and the identified stakeholders for corporate goals (Crane et al., 2008). Despite scholarly critiques, the inclusion of societal expectations remained a prominent consideration in CSR initiatives.

During the mid to late 1900s corporations began to focus on large high-profile social issues expanding beyond the local community. The purpose of the shift was to find scalable ways to make a significant impact to society while maintaining financial stability. Participating in high-profile causes can provide opportunities to increase positive perceptions of the corporation, strengthen financial performance, and gain access to new markets (Bendell, 2009). Pollution, racism, and poverty were large scale issues addressed on regional levels and transcended into the global market (Crane et al., 2008).

As corporations began expanding operations internationally in the late 1900s and beyond, community welfare, employee welfare, and environmental issues were evident. CEOs discovered in developing countries; communities were impoverished, labor was cheap, and natural resources were abundant in the environment. Economic, legal, and political conditions were also vastly different than the US; allowing room for individual interpretation of processes, unregulated business activity, corporate greed and scandal (Shaw et al., 2012).

To protect the interests of developing countries and to regulate business behaviors of multinational corporations (MNCs), a CSR business strategy was included into the process of pursuing new mar- 
kets (Allouche, 2006). MNCs shifting from a reactive position of donating time and resources to a proactive position for prevention/ problem solving analysis on a global scale provided the foundation for CSR Theory. As the third primary theory of CSR, CSR Theory, states corporations must make profits while positively contributing to the welfare of local and global communities (Idowu \& Louche, 2011).

Profit and welfare positions provide community welfare value and is driven by morality to demonstrate a corporate consciousness. Practical actions for CSR Theory are developed according to four non-financial constructs: environmental, legal, ethical, and philanthropic (Brusseau, 2017). Philanthropy is considered a social construct while legal and ethical constructs are grouped together under governance. The result is referred to as ESG performance containing three constructs: environmental, social, and governance.

\section{CORPORATE SUSTAINABILITY}

Corporate sustainability has multiple definitions ranging from the very broad to very specific depending on context framework, historical period, and scholar of reference (Rezaee 2016). Sustainability is a moving target continuing to define business models, strategy, business processes, and reporting structures (Klettner, Clarke, \& Boersma, 2014) to achieve four known CSR benefits: cost reduction, competitive advantage, synergistic value creation, and trusting reputation (Crane et al., 2008). The preceding benefits are complimentary to earlier mentioned goals of building brand equity, establishing trust, and improving leadership effectiveness. Corporate sustainability is reviewed as a continuous process of analyzing performance outcomes (financial and nonfinancial) over time (Elkington, 1997; Gao, 2008; Müller \& Pfleger 2014; Wu et al., 2013). The foundations of a continuous process were initiated by WCED in 1987 in efforts to ensure future generations are not adversely affected or killed by the actions of fore-fathers.

Understanding stakeholder needs is a key element in building long-term relationships. Stakeholders are customers, shareholders, suppliers, employees and the surrounding community of a corporation. Freeman and Dmytriyev (2017) states stakeholder interests must be incorporated into the valuation and trade-offs between stakeholders must be avoided (p. 4). Stakeholder interests are best illustrated by the Clarkston Center for Business Ethics (1999) listed in Table 2. The seven principles listed should be applied within the CSR initiative to identify business activities aligning with society expectations. CEOs must position themselves and the corporation in a manner to regularly communicate to understand stakeholder needs and expectations.

Szwajkowski (2000) states the flow of information between the corporation and stakeholders is crucial. "Honest disclosure breeds control of information, control of behavior empowerment on stakeholder issues, and perhaps most important, trust" (p. 389). Forbes author Dina Medland (2015) suggests implementing private industry tools to identify social issues relevant to stakeholders and creating a matrix based network to prioritize. Corporations must establish trust within their community of operations to achieve long-term business sustainability (Idowu \& Louche, 2011).

Once trust is established and CEOs understand stakeholder needs and societal expectations, the next step is analyzing the four constructs of stakeholder valuation for overall corporate sustainability; financial performance, environmental performance, social performance, and governance performance (RobecoSAM 2016). Examples of the key performance indicators (KPIs) are listed in Appendix A by construct. To successfully implement corporate sustainability or transformation, the entire organization must transform core operational processes and human-resource interaction (Borland, 2009; Droll, 2013; Muja, Appelbaum, Walker, Ramadan, \& Sodeyi, 2014). Transformation begins with a unified acceptance of corporate social responsibility strategy into everyday business operations. Leaders must champion the strategy and push the ideology throughout the entire corporation. 
Table 2. Principles of Stakeholder Management

\begin{tabular}{|c|c|}
\hline Number & Description \\
\hline Principle 1 & $\begin{array}{l}\text { Managers should acknowledge and actively monitor the concerns of all legitimate stakeholders and should } \\
\text { take their interests appropriately into account in decision-making and operations. }\end{array}$ \\
\hline Principle 2 & $\begin{array}{l}\text { Managers should listen to and openly communicate with stakeholders about their respective concerns and } \\
\text { contributions, and about the risks that they assume because of their involvement with the corporation. }\end{array}$ \\
\hline Principle 3 & nd modes of behavior that are sensitive to the concerns and capabilities \\
\hline Principle 4 & $\begin{array}{l}\text { Managers should recognize the interdependence of efforts and rewards among stakeholders and should } \\
\text { attempt to achieve a fair distribution of the benefits and burdens of corporate activity among them, taking } \\
\text { into account their respective risks and vulnerabilities. }\end{array}$ \\
\hline Principle 5 & isks and \\
\hline Principle 6 & $\begin{array}{l}\text { s should avoid altogether activities that might jeopardize inalienable human rights (e.g., the right to } \\
\text { ive rise to risks which, if clearly understood, would be patently unacceptable to relevant stakehold- }\end{array}$ \\
\hline Principle 7 & $\begin{array}{l}\text { Managers should acknowledge the potential conflicts between (a) their own role as corporate stakeholders, } \\
\text { and (b) their legal and moral responsibilities for the interests of stakeholders, and should address such con- } \\
\text { flicts through open communication, appropriate reporting and incentive systems, and, where necessary, third } \\
\text { party review. }\end{array}$ \\
\hline \multicolumn{2}{|c|}{$\begin{array}{l}\text { Note. Adapted from Principles of Stakeholder Management: The Clarkson Principles, by Clarkson Centre for Business } \\
\text { Ethics, Toronto, Canada, Unknown, p. 4. Copyright } 1999 \text { by University of Toronto. Adapted with permission. }\end{array}$} \\
\hline \multicolumn{2}{|c|}{$\begin{array}{l}\text { Corporate Governance Performance (CGP) is an investor value driven performance indicator de- } \\
\text { fined by the International Federation of Accountants Committee (2003) as "the set of responsibili- } \\
\text { ties and practices exercised by the board and executive management with the goal of providing stra- } \\
\text { tegic direction, ensuring objectives are achieved, ascertaining risks are managed appropriately and } \\
\text { verifying the organization's resources are used responsibly" (p.6). Corporate leadership and a host of } \\
\text { other gatekeepers are responsible for ensuring financial stability, trust, and investor confidence in the } \\
\text { corporation (Brockett \& Rezaee 2,012). The implementation of the Sarbanes-Oxley Act of } 2002 \text { and } \\
\text { the Dodd-Frank Act of } 2010 \text { were two regulatory policies put in place to increase gatekeeper ac- } \\
\text { countability to investors and the public. Each Act was created following a financial scandal or unethi- } \\
\text { cal practices resulting in a widespread crisis. }\end{array}$} \\
\hline \multicolumn{2}{|c|}{$\begin{array}{l}\text { CGP includes business ethics as a mandate of organizational accountability for moral principles, } \\
\text { standard business practices, and internal controls. Governance also provides transparency through } \\
\text { monitoring and incentives aligning with investor interests (Henriques \& Richardson, 2004). Success } \\
\text { of CGP is reliant upon the CEO leadership and their ability to create an organizational culture of } \\
\text { integrity. Ethics, integrity and transparency build trust and increases brand equity; important features } \\
\text { in creating value for investors. Businesses fail to exist when CEO leadership and others within the } \\
\text { company fail to make thoughtful, intelligent, wise, and ethical decisions (Carroll et al., 2012). }\end{array}$} \\
\hline \multicolumn{2}{|c|}{$\begin{array}{l}\text { Corporate Environmental Performance (CEP) is a community welfare driven performance indicator, } \\
\text { defined by the United States Environmental Protection Agency (2011) as "the measurable results of } \\
\text { the environmental management system, related to an organization's control of its environmental as- } \\
\text { pects, based on its environmental policy, objectives, and targets" (p. 1). Changes to the environment } \\
\text { is a shared problem and corporations controlling the surrounding environment are responsible for } \\
\text { protecting future generations. Such actions are considered external business operations and are in- } \\
\text { cluded in public image and brand protection initiatives. Brockett and Rezaee (2012) states over the } \\
\text { past decade, the well-being of society has greatly benefited from corporate environmental policies. }\end{array}$} \\
\hline & \\
\hline
\end{tabular}


accountability based on society values (Brockett \& Rezaee 2012). In other words, finding goals sharing the needs of the community while conducting business with integrity; even when the corporation is not at fault. To understand the needs of the community and reduce reputational risk, the corporation must find ways to engage and interact with the community (Herriott, 2016; Medland, 2015). KPIs assigned to CSP address internal and external business operations to maintain and protect basic human rights.

Corporate Financial Performance (CFP) is an investor value driven performance indicator defined by Karlson (2016) as "measurable value that indicates how well a company is doing regarding generating revenue and profits" (p. 1). Like CGP, corporations must establish trust and financial stability through the external compliance of the Sarbanes-Oxley Act of 2002 and the Dodd-Frank Act of 2010 to attract capital investors. Reliability of finances are essential for investor confidence and efficient capital markets (Brockett \& Rezaee, 2012). To improve transparency and gatekeeper accountability, internal controls such as executive certifications and audit oversight committees were implemented (p. 95).

\section{HOLISTIC CONCENTRIC CIRCLES MODEL}

The third goal of the current study is introducing a paradigm shift in defining and analyzing corporate sustainability constructs to create a holistic view for equal consideration of financial and nonfinancial performance. The shift evolves from concentric circles (WCED, 1987) and hierarchal pyramids (Carroll, 1991) to create a holistic view illustrating the shared value and equal consideration among all four constructs; financial performance, environmental performance, social performance, and governance performance. Figure 1 contains the evolution of concentric circles from 1971 to the holistic view proposed here.

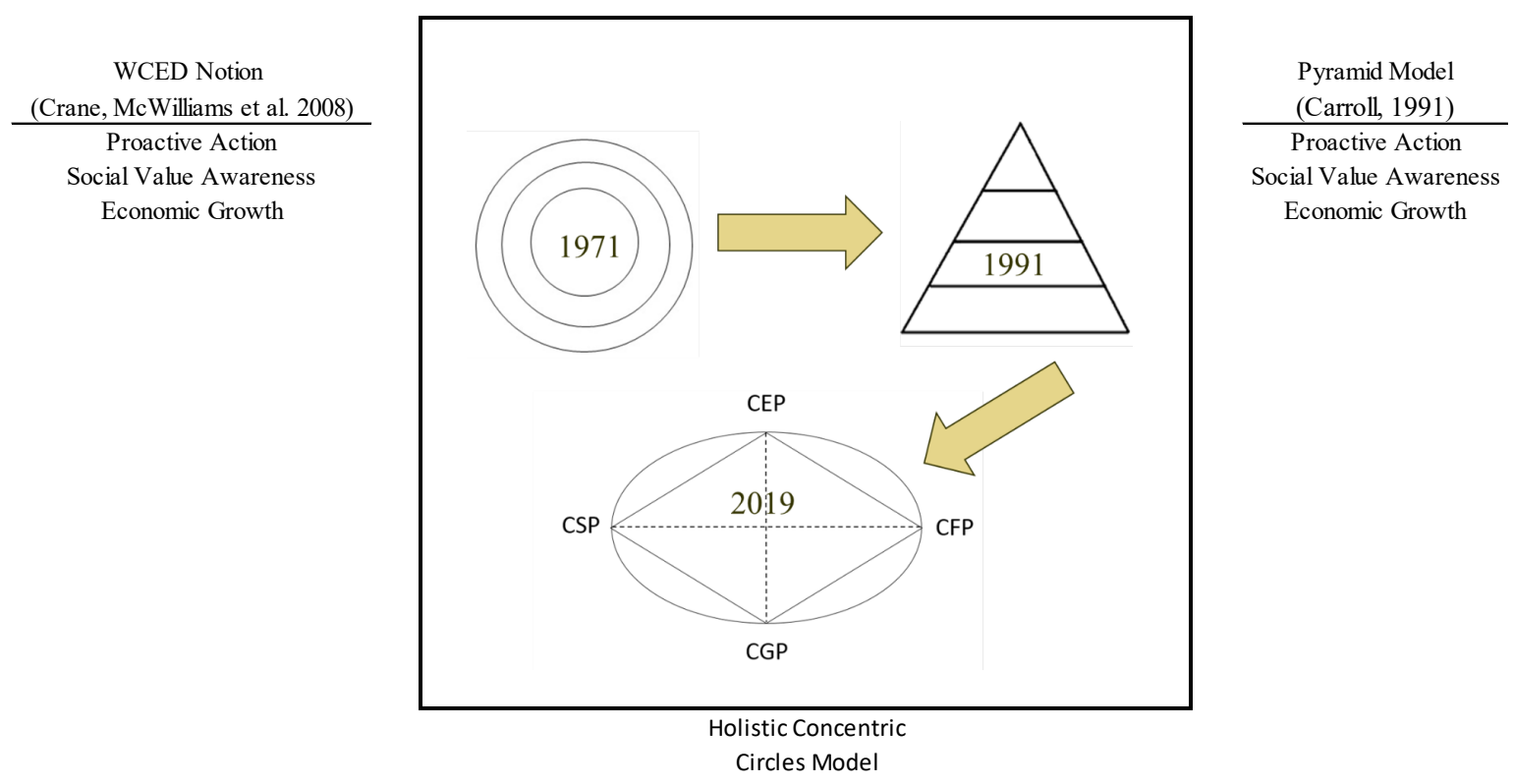

Figure 1. The evolution of the concentric circles model. WCED $=$ World Commission on Environment and Development; CGP = corporate governance performance; $\mathrm{CEP}=$ corporate environmental performance; $\mathrm{CSP}=$ corporate social performance; $\mathrm{CFP}=$ corporate financial performance.

The evolutionary journey of the Concentric Circles Model begins with the 1971 concentric circles notion of social responsibility presented by WCED (Crane et al., 2008). The notion articulates for corporations to meet the needs of society, the society must be satisfied with the quality of services 
rendered. The three circles of economic growth, social value awareness, and proactive action, represent the first set of performance outcomes (constructs) as related to CSR and sustainability.

The Pyramid Model presented by one of the founding sustainability theorists Archie B. Carroll (1991), expounds upon the WCED notion and groups business responsibilities into a hierarchal structure. The integration between constructs is removed to provide a more rigid procedure-based approach with higher priority responsibilities at the base. Like Maslow's Hierarchy of Needs for the human condition, the upper levels of the pyramid are not addressed until the lower levels are completely satisfied. Philanthropy was added as a discretionary category to capture the philanthropic activity gaining momentum in the late 1800s to early 1900s (Geva, 2008). Although helping others is a value-added business activity, participation was voluntary and not considered high priority (p. 7).

The Holistic Concentric Circles Model takes the four constructs of sustainability and applies the allinclusive integration of the WCED notion. Each point of the diamond within the circle represents the performance outcomes; Corporate Financial Performance (CFP), Corporate Environmental Performance (CEP), Corporate Social Performance (CSP) and Corporate Governance Performance (CGP). The all-inclusive integration brings a holistic view to sustainability where a CSR initiative may satisfy multiple constructs concurrently, in any combination or none. Corporate leadership are liberated to address stakeholder value, investor value, \& community welfare interests to pursue a holistic vision of sustainability performance.

\section{THEORETICAL BACKGROUND}

As a hot topic of diversity, gender studies are increasingly popular because of the male dominated presence as leaders in the global business market (Adler, 1997; Chen, 2001; Hoffman, 2013; Marshall \& Hopfl, 2007). Diversity is defined by Kapoor (2011) as an avenue to provide opportunities for minorities and women in the workplace. Over time, the focus of diversity shifted from individual mindsets to a broader spectrum of organizational culture. Diversity has evolved from simply black vs. white and male vs. female to become "all-inclusive of every way people can be different" (p. 286).

Studies have shown globally women in general, are not considered for international business management even though women may be more qualified than their male counterpart (Doerre, 2001; Hutchings, Metcalfe, \& Cooper, 2010). Although this research and similar studies (Accenture, 2014; Catalyst, 2016; Hernandez Bark, Escartín, Schuh, \& van Dick, 2015; Kim \& Starks, 2016; Vanderbroeck, 2010) highlight the underrepresentation of female leadership in the global market, the underlying root cause is not definitive. Upper Echelon Theory and Social Role Theory provide empirical evidence in context applicable to differences in male and female business strategy development and prioritize ethical considerations to achieve overall corporate sustainability goals.

\section{UPPER ECHELON THEORY}

Although early empirical studies were grounded in behavior based theories, the Upper Echelon Theory evolved to embrace demography and heterogeneity influences on corporate strategy and performance (Nielsen, 2009). Personal perceptions are built from the characteristics created by demography and heterogeneity influences in a given period of time such as childhood, professional experience or other situations formulating parameters for social norms.

CEOs and executive leadership make decisions based on personal and professional experiences (demographic characteristics) impacting value creation (stakeholder and investor), community welfare, and the actions producing corporate performance outcomes (Hambrick \& Mason, 1984; Jeong \& Harrison, 2017; Nielsen 2009). Gender is a demographic characteristic drawing much interest in the production of corporate performance outcomes (Feng et al., 2017; Ho et al., 2014; Khan \& Vieito, 2013) included in sustainability. 
Post and Byron (2015) illustrated a direct relationship between gender-related professional experiences and corporate performance outcomes. The results suggest that female executives had a positive effect on corporate financial performance and overall strategy for the period. Jeong and Harrison (2017) results indicated that female executives have negative short-term market returns but positive long-term effects on corporate performance. The empirical evidence supports the idea that female leadership improves corporate performance (Moreno-Gómez, Lafuente, \& Vaillant, 2018). Although individual experiences were not tested in this study, the empirical evidence should consistently reveal gender differences in the sustainability results.

\section{SOCIAL ROLE THEORY}

Social Roles Theory began in 1984 as an explanation for gender role stereotypes (Koenig \& Eagly, 2014). Societal beliefs defined the acceptable roles of women and men and assigned value through the characteristics of the accepted role. In Koenig and Eagly (2014) sample, women who cared for children were nurturing, warm and sensitive; these valued characteristics have become a standard for women in society. As an observer's established standard, similar feminine characteristics are ap-plied to every female person (Kiser, 2015), and this behavior is expected to be consistent in all situations (Eagly, 1987), including in corporate leadership.

Individual demographic and heterogeneity influences learned from childhood and work experience shape how gender characteristics are valued (Gilligan, 1982). Corporate leadership use personal perception through experiences to make decisions, develop business strategy and prioritize ethical considerations. At times corporate leadership behavior may conflict with gender stereotypes to do what is best for the organization (Boulouta, 2012). Women in leadership roles may have to abandon nurturing, caring and sensitive characteristics and replace feminine characteristics with masculine characteristics.

Gender bias is presented when the actions of a leader are inconsistent with an evaluator's belief of appropriate behavior for the gender (Weyer 2007). "Generally, agentic traits are ascribed to men and communal behaviors are ascribed to women" (p.485). As mentioned previously a woman abandoning sensitivity characteristics would be scorned as unacceptable and unworthy of the leadership position. However, in similar situations, men demonstrating male gender stereotypes such as masculinity, are more acceptable in leadership roles (Lamsa, Sakkinen, \& Turjanmaa, 2000; Ryan \& Haslam, 2007; Schein, Muller, Lituchy, \& Liu, 1996).

Previous literature shows female gender stereotypes have produced positive impacts on board performance (Daily, Dalton, \& Cannella, 2003; Nielsen \& Huse 2010), CSR (Burges \& Tharenou, 2002; Huse, Nielsen, \& Hagen, 2009; Ibrahim \& Angelidis, 1994), and stakeholder needs (Bear, Rahman, \& Post, 2010). Recent studies such as Boulouta (2012) and Velte (2016) indicate a positive relationship between the female presence of corporate leadership and sustainability performance. Kim and Starks (2016) provides additional support by indicating female corporate leaders are more likely to diversity board membership and contribute unique skills proven to increase firm value. Corporate leadership behaviors producing value creation and positive corporate performance outcomes establish trust, build brand equity, and improve leadership effectiveness.

\section{CORPORATE SUSTAINABILITY AND FIRM PERFORMANCE}

According to a study conducted by the Audit Committee Institute, noted over $50 \%$ of the corporate leadership in large companies believe focusing on sustainability provides a competitive advantage in corporate performance (KPMG, 2018). Feng, Wang et al. (2017) supported KPMG by identifying significant positive correlations between CSR activities and firm financial performance across multi-

ple industries. Feng, Wang et al. were the first scholars to provide empirical evidence of homogenous application of CSR's impact on firm performance. 
In the early years of CSR research, enthusiasts such as McWilliams, Siegel, and Wright (2006) conducted a comprehensive analysis on available CSR strategies and the theoretical implications on firm financial performance. The results summarized available CSR strategies were considered highly effective for improving firm financial performance. A wide range of studies spanning twelve years echo favorable consideration with empirical evidence of support (Feng et al., 2017; Mackey, 2005; Whalen, 2013).

The results of a Harvard University study revealed "finally, we provide evidence that High Sustainability companies significantly outperform their counterparts over the long-term, in terms of stock market as well as accounting performance" (Eccles, Ioannou, \& Serafeim, 2014). High Sustainability companies were defined as corporations adopting sustainability policies before the international movement in the late 1900s (p. 1). Although the KPMG (2018) study noted that less than $47 \%$ of small businesses owners do not believe sustainability improves corporate performance, a study conducted by Srichatsuwan (2014) provides evidence of strong correlations between CSR strategies and firm performance in small businesses.

\section{HYPOTHESIS DEVELOPMENT}

As previously discussed, there is limited research linking the long-term effectiveness of corporate leadership gender to sustainability performance. The researcher believes that sustainability is an area of opportunity to increase the number of women in corporate leadership. A year over year quantitative analysis is conducted to determine relationships between corporate leadership gender, financial performance, environmental performance, social performance, and governance performance moderated by industry. All positions of corporate leadership (CEO, C-Suite, and Board of Directors) are examined and results incorporated into the concentric circles model to propose a holistic view of sustainability performance. The following research questions and hypotheses are explored to achieve the objectives for the study:

RQ1: What is the impact of CEO gender on year over year corporate sustainability in North American organizations?

H1: CEO gender has a positive impact on year over year corporate sustainability.

H2: Female CEOs have a higher positive impact than male CEOs on year over year corporate sustainability.

RQ2: What is the impact of C-Suite gender on year over year corporate sustainability in North American organizations?

H3: Female C-suite presence has a positive impact on year-over-year corporate sustainability.

H4: Female C-Suites have a higher positive impact than male C-Suites on year over year corporate sustainability.

RQ3: What is the impact of female board members on year over year corporate sustainability in North American organizations?

H5: Female board member presence has a positive impact on year over year corporate sustainability.

H6: Female board member presence have a higher positive impact than male only board member presence on year over year corporate sustainability.

H7: There is a positive relationship between year over year firm performance and corporate sustainability. 


\section{DATA AND METHODOLOGY}

\section{DATA AND SAMPLE SELECTION}

The population of data to measure sustainability (ESG) performance begins with the annual Corporate Sustainability Assessment (CSA) collected by the private investment firm RobecoSAM (2016). The CSA is an industry trusted tool used to collect data from over 3,400 multinational and large publicly traded companies. RobecoSAM uses the CSA to assign a score to each performance metric and releases the information to approve sources for research or analytical purposes. The assessment contains up to 120 questions capturing general and industry level information measured on a 100-point proprietary weighted scale. Scores are assigned to CEP, CSP, CGP and overall total for each participating organization. Overall total scores are ranked on a scale of 1 to 100 by industry (CSRO) and released to approved sources.

One approved source is S\&P Dow Jones Indices, a joint venture corporation providing global financial market indices to industry professionals (S\&P, 2018). The Dow Jones runs a proprietary rule based ranking algorithm on the CSA sustainability scores to calculate the "top 10\% most sustainable market caps per industry" (RobecoSAM 2016). Dow Jones scores are then published with Bloomberg, a privately held financial, software, data and media company headquartered in New York City (2018).

A second approved source is Sustainalytics (2018), a privately held financial services company headquartered in Amsterdam. As a trusted partner of Dow Jones since 2000, and Bloomberg L.P, since 2014, Sustainalytics continues to be a reputable resource for analyzing and publishing sustainability scores. Sustainalytics scores are created by running a proprietary asset weighted based ranking algorithm on 70 factors by level of importance and industry peers (Hale, 2016). The sample of 99 CSA participants were selected from the S\&P 500 Dow Jones Sustainability North American Composite Index reporting sustainability scores consecutively from 2014 to 2017.

The researcher retrieved ESG performance, overall sustainability ranking (CSRO), general firm information and financial data from an authorized Bloomberg terminal with the appropriate credentials. For Dow Jones, the ESG and CSRO data are only available for 2017. For Sustainalytics, the data are available for the full testing period, from 2014 to 2017. Following Post and Byron (2015), the researcher selected these financial metrics referred to as CFP: return on equity (ROE), return on investment capital (ROIC), return on assets (ROA), and profit. The researcher then used q ratio (overall investment value) and $z$ score (overall investment risk) to add value to the holistic perception of corporation health (Elsaid, 2014). The researcher calculated the Tobin's q values manually according to the method that Smith and Watts (1992) established.

\section{DATA CODING AND ANALYSIS}

Consistent with previous studies in leadership gender, the researcher coded female CEOs as 1 and male CEOs as 0 (Jeong \& Harrison, 2017 Female CEOs comprise 5\% of the total North American sample (5 females to 94 males). Figure 2 illustrates the corporation and gender counts by industry. The low percentage of female CEO representation is consistent with the male dominated presence as leaders in the global business market (Adler, 1997; Chen, 2001; Hoffman, 2013; Javidan et al., 2016; Marshall \& Hopfl, 2007). Corporation presence is strong in all industries excluding Communication Services. 


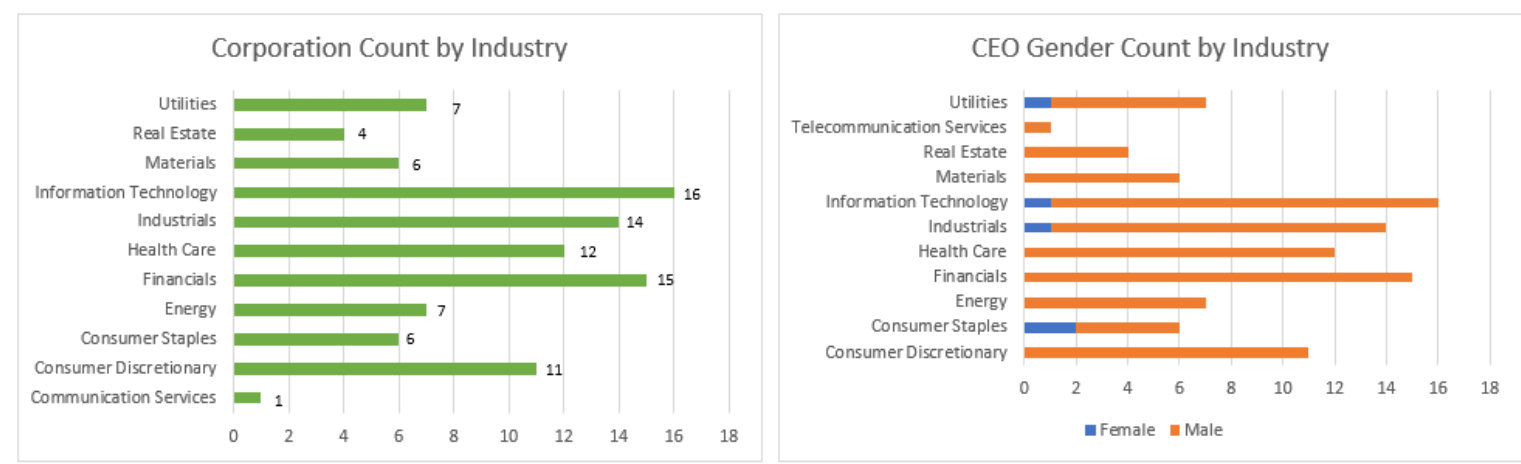

Figure 2. Corporations and CEO gender, by industry. Panel a) is the number of corporations in each industry; b) is the number of women and men in each industry.

GIC Industry was coded with a numeric value ranging from 1 to 11 in sequence. Percentage representation of female and male C-Suite and Board of Directors were grouped into four categories in descending order: Greater than 75\%, 51 to $75 \%, 26$ to $50 \%$ and 25 or less. The categories provide four independent groups in which to test year over year significant differences by gender. Percentage representation of female C-Suite and Board of Directors with a female CEO and without a female $\mathrm{CEO}$ were grouped into eight categories presented in Table 3 . The eight groups allow testing by the combination of female presence in leadership roles. Figure 3 illustrates the combination groups for 2017 as a dataset and by industry.

Table 3. Female C-Suite and Board of Director Representation

\begin{tabular}{cl}
\hline Category & \multicolumn{1}{c}{ Description } \\
\hline 1 & Greater than 33\% female directors AND greater than 33\% female C-suite members \\
2 & Greater than 33\% female directors AND no more than 33\% female C-suite members \\
3 & No more than 33\% female directors AND greater than 33\% female C-suite members \\
4 & No more than 33\% female directors AND at most 33\% female C-suite members \\
5 & Same as Category 1, except with a female CEO \\
6 & Same as Category 2, except with a female CEO \\
7 & Same as Category 3, except with a female CEO \\
8 & Same as Category 4, except with a female CEO \\
\hline
\end{tabular}

The single available dataset was split into two datasets containing the same general firm information and financial data. For Dataset A, 2017 ESG performance and CSRO for Dow Jones and Sustainalytics were added. For Dataset B, 2014 to 2017 ESG performance and CSRO data for Sustainalytics was added. Initial tests were performed to secure the appropriate statistical technique and analytical approach. The Test of Normality was applied to Dataset A and Dataset B and each indicated deviations within the Kolmogorov-Smirnov statistic results.

The Test of Multivariate Normality was also applied to Dataset A and Dataset B and each indicated a Mahalanobis (Mahal) Distance greater than the critical value assigned for the number of dependent variables at 0.001 degrees of freedom. The greater value indicates there are substantial outliers for these datasets that cannot be removed. For comparison, the Multivariate Normality was calculated a second time for both datasets and excluded the financial performance variables resulting in a Mahal Distance less than the critical value. This change in Mahal is an indication the financial performance variable are the substantial outliers and the 2017 ESG performance and 2017 CSRO scores for Dow Jones and Sustainalytics are similar enough to exclude Dow Jones from the 2014 to 2017 analysis. 

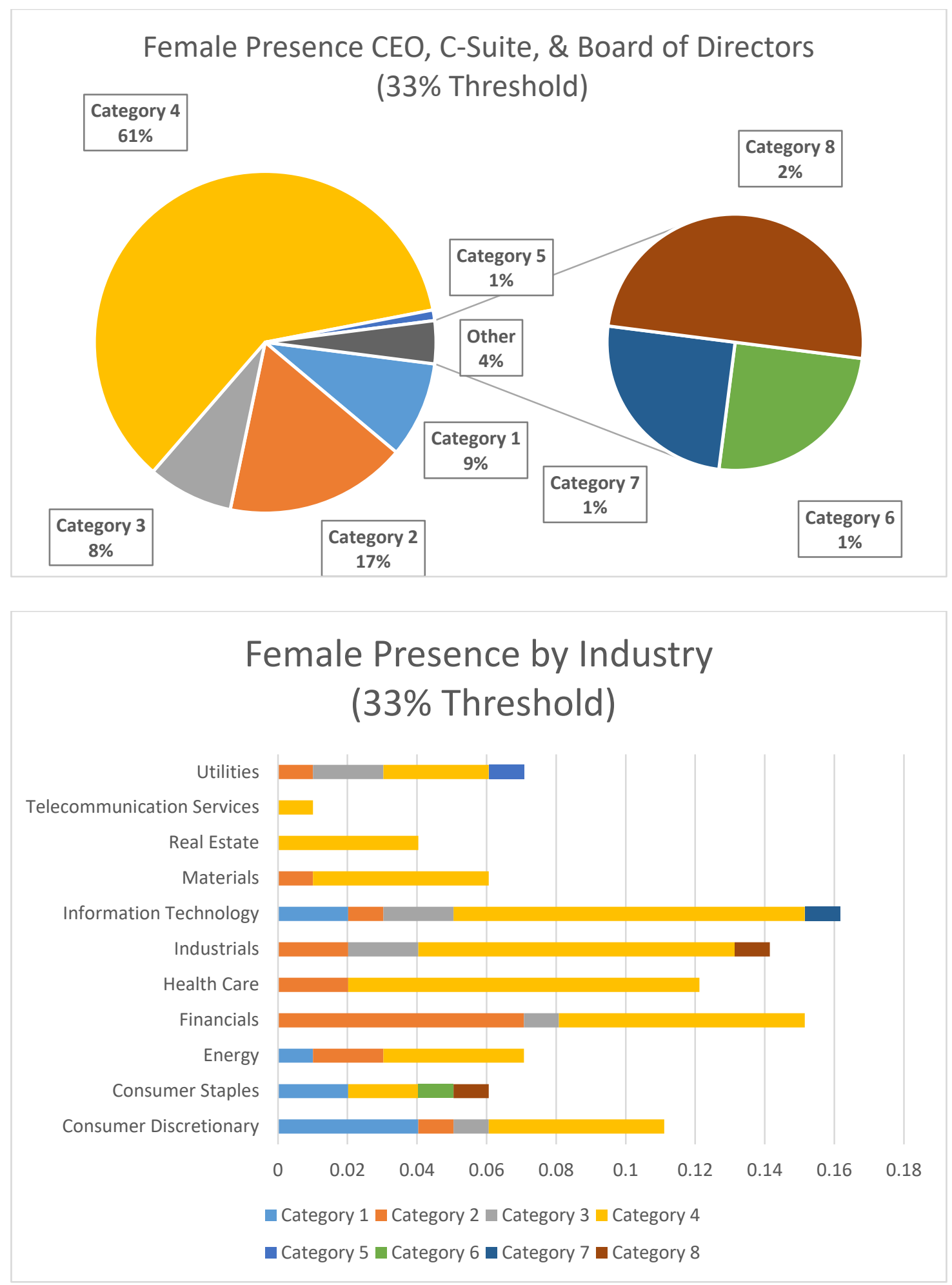

Figure 3. Combination female representation, 2017. Panel a) is the total female representation of $\mathrm{C}$-suite members and directors by category as defined in Table 3 . Three categories $(6,7, \& 8)$ make up the $4 \%$ labeled as "other". Panel b) is the same total from panel a) grouped by industry.2017 
To illustrate the similarity between Dow Jones and Sustainalytics data, averages for CEO gender, ESG performance, and CSRO by industry are calculated. The results of the normality tests as indicated above determines the nonparametric method is the appropriate analytical approach. The Friedman Test was used to determine significant changes across dependent variables from 2014 to 2017. The Wilcoxon Signed Ranks Test was used to determine effect size of significant changes. The Mann-Whitney U Test was used to determine if significant changes crossed independent groups (i.e. CEO gender) accompanied by Means Table Median scores (H2). The Kruskal-Wallis Test was used to determine differences across C-Suite and Board of Director groups (H4 \& H6). Correlations, descriptive statistics and other illustrative graphs provide evidence of remaining hypotheses $(\mathrm{H} 1, \mathrm{H} 3$, $\mathrm{H} 5$, and $\mathrm{H} 7$ ).

\section{RESULTS}

\section{DATASET A}

Dataset A contains 2017 values for ESG performance and CSRO for Dow Jones (DJ) and Sustainalytics (SS) along with general firm information and financial data. Descriptive statistics for ESG performance and CSRO by industry were calculated. The Kolmogorov-Smirnov values for goodness of contains values less than the significance value of .05 indicating abnormal distributions (Pallant, 2016). The results show CEP, CSP, and CGP performance are abnormal for Dow Jones and Sustainalytics across seven industries (Table 4).

For this study, financial performance is included to present a holistic analysis of corporate sustainability. Descriptive statistics for ESG performance and CSRO by industry are constant for Communication Services industry resulting in exclusion from the output. The output also suggests that clustering is high and to the right with extremes causing a relatively flat distribution (p.57). The next set of figures illustrate the similarities between Dow Jones and Sustainalytics for ESG performance, CSRO, and CEO gender by industry.

Table 4. Descriptive Statistics for Industries with Abnormal Distributions, 2017

\begin{tabular}{|c|c|c|c|c|c|c|c|c|c|}
\hline \multicolumn{10}{|c|}{2017} \\
\hline Performance & GIC Industry & $n$ & Mean & Md & SD & Min & Max & Skewness & $\begin{array}{c}\text { Kol-Smirnov } \\
\text { (Sig) }\end{array}$ \\
\hline \multicolumn{10}{|l|}{ Sustainalytics } \\
\hline \multirow[t]{3}{*}{ CEP } & Industrials & 14 & 62.25 & 69.18 & 62.25 & 20.39 & 22.20 & -1.015 & 0.011 \\
\hline & Information Technology & 15 & 84.23 & 86.08 & 84.23 & 14.38 & 40.50 & -2.114 & 0.027 \\
\hline & Materials & 5 & 63.51 & 75.00 & 63.51 & 33.73 & 5.30 & -1.843 & 0.035 \\
\hline \multirow[t]{2}{*}{ CSP } & Consumer Discretionary & 11 & 83.62 & 88.73 & 83.62 & 12.72 & 53.80 & -1.723 & 0.004 \\
\hline & Industrials & 14 & 69.60 & 81.71 & 69.60 & 22.65 & 21.90 & -0.772 & 0.017 \\
\hline CGP & Industrials & 14 & 73.91 & 85.13 & 73.91 & 22.81 & 12.70 & -1.808 & 0.014 \\
\hline \multicolumn{10}{|l|}{ Dow Jones } \\
\hline \multirow[t]{2}{*}{ CSRO } & Consumer Staples & 6 & 83.17 & 85.00 & 83.17 & 11.05 & 62.00 & -1.798 & 0.043 \\
\hline & Industrials & 14 & 82.14 & 84.00 & 82.14 & 13.10 & 55.00 & -0.979 & 0.028 \\
\hline CEP & Energy & 7 & 76.71 & 83.00 & 76.71 & 16.02 & 50.00 & -1.139 & 0.012 \\
\hline CSP & Materials & 6 & 90.33 & 96.00 & 90.33 & 12.16 & 72.00 & -0.979 & 0.024 \\
\hline CGP & Utilities & 7 & 75.29 & 73.00 & 75.29 & 9.52 & 67.00 & 2.199 & 0.005 \\
\hline
\end{tabular}

Note. GICS = Global Industry Classification Standard; Min. = minimum; Max. = maximum; CEP = corporate environmental performance; $\mathrm{CSP}=$ corporate social performance; $\mathrm{CGP}=$ corporate governance performance; $\mathrm{CSRO}=$ corporate social responsibility-overall. 
The first set of graphs in Figure 4 show the average ESG performance and CSRO for Dow Jones and Sustainalytics in 2017. Although the Dow Jones averages are slightly higher, the flow and distribution of values across industries are similar. The second set of graphs in Figure 5 illustrate average CSRO for female and male CEOs by industry. Female CEO presence is limited to four industries; only approximately $30 \%$ of the total market. To ascertain differences in gender influence on ESG performance and CSRO, comparison graphs were created for the shared industries; consumer staples, industrials, information technology, and utilities. The results show in several graphs across different industries for Dow Jones and Sustainalytics, female CEOs produce a higher average than male CEO competitors. One prominent example is Consumer Staples showing higher Dow Jones and Sustainalytics values for female CEO within CEP, CSP, and CSRO performance scores.
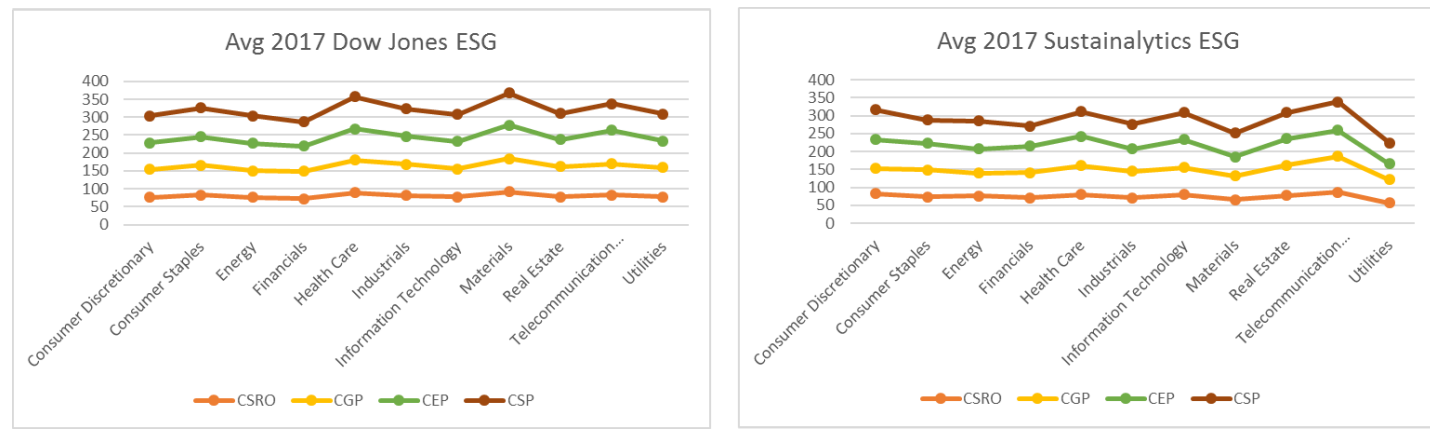

Figure 4. Average environmental, social, and governmental (ESG) performance and overall corporate social responsibility $(\mathrm{CSRO})$ by industry, 2017. CGP $=$ corporate governmental performance; $\mathbf{C E P}=$ corporate environmental performance; $\mathbf{C S P}=$ corporate social performance. Panel a) are the averages for the Dow Jones reporting entity and b) are the aver-ages for Sustainalytics.
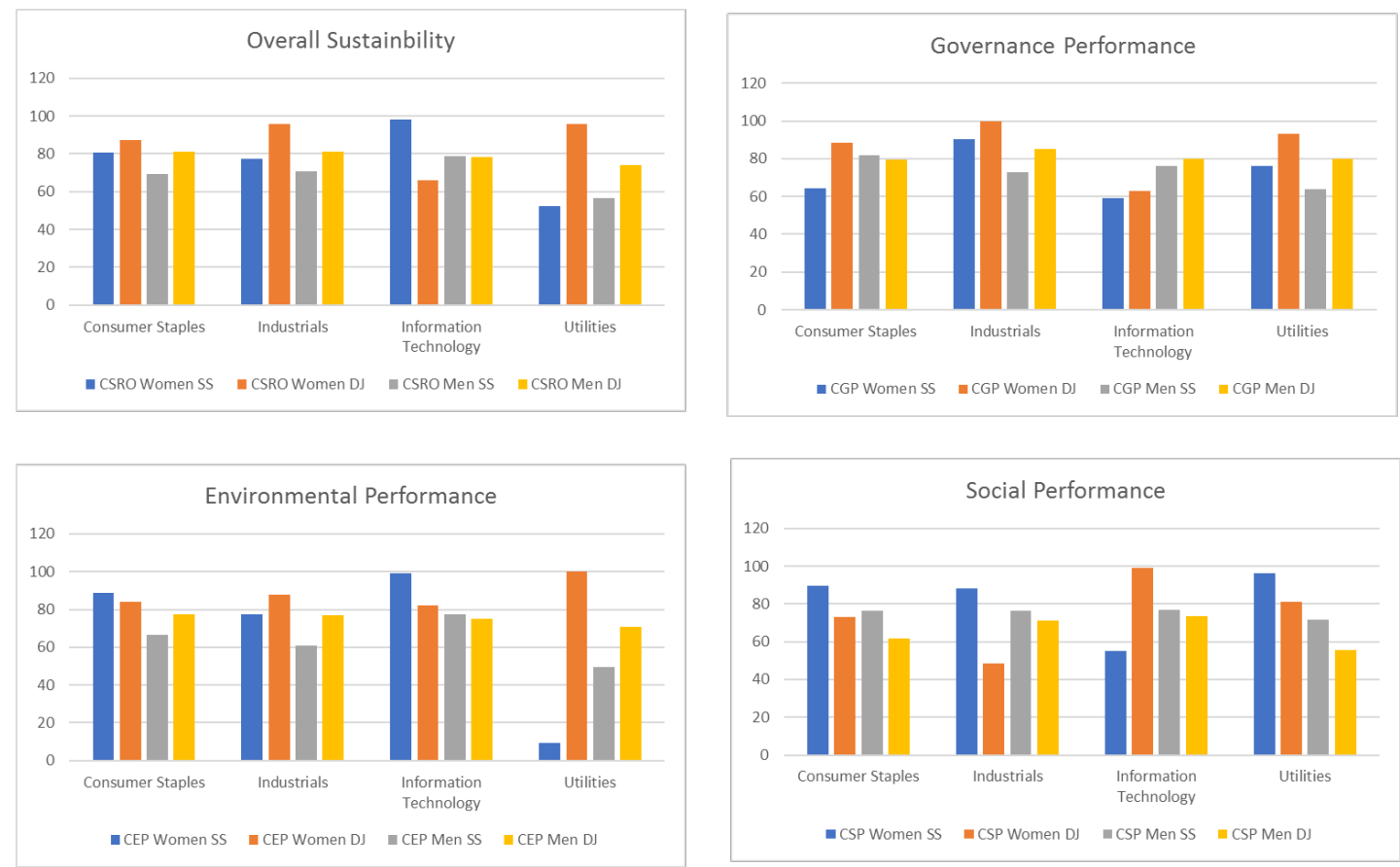

Figure 5. Average overall, governance, environmental, and social performance by CEO gender and industry, 2017. DJ = Dow Jones; SS = Sustainalytics; CGP = corporate governance performance $\mathbf{C E P}=$ corporate environmental performance; $\mathrm{CSP}=$ corporate social performance; $\mathbf{C S R O}=$ corporate social responsibility-overall. Panel a) are the CSRO averages and panels b) through d) are the ESG averages. 


\section{DATASET B}

Dataset B contains 2014 to 2017 values for ESG performance and CSRO for Sustainalytics along with general firm information and financial data. The values for Dow Jones were not available for 2014 to 2016 via the Bloomberg terminal. Descriptive statistics for all performance variables (ESG, CSRO, and financial) by industry were calculated. The Kolmogorov-Smirnov values for goodness of fit for 2014 to 2017 indicates abnormal distributions presented in Table 5. The results show abnormal distribution values across all performance variables, years, and industries.

Table 5. Descriptive Statistics for the Abnormal Distributions, 2014-2017

\begin{tabular}{|c|c|c|c|c|c|c|c|c|c|}
\hline \multicolumn{10}{|c|}{2014} \\
\hline Performance & GIC Industry & $n$ & Mean & Md & SD & Min & Max & Skewness & $\begin{array}{c}\text { Kol-Smirnov } \\
\text { (Sig) }\end{array}$ \\
\hline CEP & Financials & 15 & 78.43 & 83.08 & 17.40 & 33.70 & 96.90 & -1.432 & 0.033 \\
\hline \multirow[t]{5}{*}{ ROE } & Energy & 7 & 17.14 & 13.61 & 7.98 & 12.27 & 34.36 & 2.198 & 0.006 \\
\hline & Health Care & 12 & 29.97 & 24.37 & 26.93 & 7.91 & 109.43 & 2.645 & 0.003 \\
\hline & Industrials & 14 & 44.21 & 34.20 & 33.01 & 17.65 & 120.51 & 1.83 & 0.011 \\
\hline & Information Technology & 16 & 26.28 & 20.09 & 30.13 & -31.47 & 102.65 & 1.089 & 0.02 \\
\hline & Utilities & 7 & 23.12 & 15.90 & 18.83 & 11.78 & 64.94 & 2.425 & 0.003 \\
\hline \multirow[t]{2}{*}{ ROIC } & Consumer Discretionary & 11 & 22.73 & 17.96 & 15.33 & 3.85 & 52.85 & 1.236 & 0.003 \\
\hline & Information Technology & 16 & 18.49 & 16.32 & 19.93 & -16.11 & 80.51 & 1.851 & 0.029 \\
\hline \multirow[t]{2}{*}{ ROA } & Health Care & 12 & 11.13 & 10.82 & 6.95 & 2.55 & 30.35 & 1.94 & 0.003 \\
\hline & Utilities & 7 & 5.00 & 4.46 & 1.70 & 3.32 & 7.74 & 1.007 & 0.049 \\
\hline Profit & Materials & 5 & 1.57 & 7.45 & 17.03 & -28.39 & 13.80 & -2.05 & 0.012 \\
\hline Z-Score & Information Technology & 16 & 6.63 & 4.76 & 6.54 & 2.06 & 27.47 & 2.575 & 0.003 \\
\hline \multirow[t]{3}{*}{ Q-Ratio } & Financials & 15 & 1.37 & 1.22 & 0.29 & 0.96 & 1.77 & 0.192 & 0.023 \\
\hline & Health Care & 12 & 2.97 & 2.43 & 1.56 & 1.17 & 6.43 & 1.41 & 0.007 \\
\hline & Utilities & 7 & 1.67 & 1.63 & 0.20 & 1.45 & 2.10 & 1.769 & 0.019 \\
\hline \multicolumn{10}{|c|}{2015} \\
\hline Performance & GIC Industry & $n$ & Mean & Md & SD & Min & Max & Skewness & $\begin{array}{c}\text { Kol-Smirnov } \\
\text { (Sig) }\end{array}$ \\
\hline CGP & Industrials & 14 & 80.93 & 84.82 & 13.97 & 39.00 & 92.90 & -2.328 & 0.033 \\
\hline CEP & Industrials & 14 & 67.82 & 77.02 & 22.08 & 28.60 & 90.50 & -0.858 & 0.03 \\
\hline ROE & Financials & 15 & 16.28 & 15.92 & 4.86 & 9.64 & 23.89 & 0.258 & 0.037 \\
\hline \multirow[t]{2}{*}{ ROIC } & Energy & 7 & -3.26 & -0.82 & 5.93 & -14.09 & 2.84 & -1.254 & 0.038 \\
\hline & Information Technology & 16 & 17.88 & 15.35 & 19.43 & -10.03 & 80.99 & 2.339 & 0.001 \\
\hline ROA & Energy & 7 & -2.45 & -0.67 & 4.48 & -10.45 & 2.37 & -1.159 & 0.045 \\
\hline \multirow[t]{2}{*}{ Profit } & Consumer Staples & 6 & 10.00 & 8.44 & 7.69 & 1.59 & 24.52 & 1.602 & 0.041 \\
\hline & Materials & 6 & 3.08 & 7.85 & 17.75 & -31.43 & 16.33 & -1.964 & 0.026 \\
\hline Z-Score & Information Technology & 16 & 6.63 & 4.76 & 6.54 & 2.06 & 27.47 & 2.575 & 0.003 \\
\hline \multirow[t]{2}{*}{ Q-Ratio } & Consumer Discretionary & 10 & 3.02 & 1.87 & 2.45 & 1.33 & 9.17 & 2.077 & 0.025 \\
\hline & Industrials & 14 & 2.31 & 1.81 & 0.98 & 1.12 & 4.01 & 0.614 & 0.017 \\
\hline \multicolumn{10}{|c|}{2016} \\
\hline Performance & GIC Industry & $n$ & Mean & Md & SD & Min & Max & Skewness & $\begin{array}{c}\text { Kol-Smirnov } \\
\text { (Sig) }\end{array}$ \\
\hline CSRO & Consumer Discretionary & 11 & 79.3 & 87.1 & 18.5 & 33.3 & 93.3 & -1.977 & 0.003 \\
\hline CGP & Information Technology & 15 & 77.9 & 85.9 & 21.6 & 31.1 & 100.0 & -1.245 & 0.045 \\
\hline CEP & Consumer Discretionary & 11 & 77.2 & 85.9 & 20.5 & 25.9 & 94.5 & -1.836 & 0.015 \\
\hline \multirow[t]{3}{*}{ ROE } & Consumer Discretionary & 11 & 45.1 & 36.1 & 28.1 & 20.3 & 117.1 & 1.952 & 0.029 \\
\hline & Information Technology & 14 & 28.1 & 20.8 & 20.9 & 0.1 & 70.6 & 1.231 & 0.009 \\
\hline & Utilities & 7 & 19.3 & 12.9 & 25.8 & -10.2 & 73.6 & 1.793 & 0.028 \\
\hline \multirow[t]{2}{*}{ ROIC } & Information Technology & 16 & 20.4 & 16.1 & 18.0 & 0.0 & 81.3 & 2.801 & 0.001 \\
\hline & Utilities & 7 & 4.4 & 4.9 & 3.4 & -2.8 & 8.1 & -1.851 & 0.014 \\
\hline
\end{tabular}


Corporate Sustainability: Corporate Leadership Impact

\begin{tabular}{|c|c|c|c|c|c|c|c|c|c|}
\hline ROA & Information Technology & 16 & 11.7 & 10.5 & 7.1 & 0.0 & 29.7 & 1.22 & 0.006 \\
\hline \multirow[t]{3}{*}{ Profit } & Energy & 7 & -20.0 & -0.5 & 48.4 & -128.8 & 6.0 & -2.541 & 0.001 \\
\hline & Health Care & 12 & 16.0 & 9.8 & 15.1 & 1.1 & 48.9 & 1.157 & 0.02 \\
\hline & Information Technology & 16 & 16.4 & 14.2 & 16.8 & -13.2 & 69.1 & 1.904 & 0.02 \\
\hline Z-Score & Information Technology & 16 & 6.6 & 4.8 & 6.5 & 2.1 & 27.5 & 2.575 & 0.003 \\
\hline \multirow[t]{3}{*}{ Q-Ratio } & Consumer Discretionary & 10 & 2.7 & 1.7 & 2.0 & 1.2 & 7.5 & 1.887 & 0.02 \\
\hline & Financials & 15 & 1.3 & 1.2 & 0.3 & 1.0 & 1.7 & 0.188 & 0.018 \\
\hline & Industrials & 14 & 2.4 & 2.0 & 1.0 & 1.3 & 4.4 & 0.805 & 0.015 \\
\hline \multicolumn{10}{|c|}{2017} \\
\hline Performance & GIC Industry & $n$ & Mean & Md & SD & Min & Max & Skewness & $\begin{array}{l}\text { Kol-Smirnov } \\
\text { (Sig) }\end{array}$ \\
\hline CGP & Industrials & 14 & 73.91 & 85.13 & 22.81 & 12.70 & 91.80 & -1.808 & 0.014 \\
\hline \multirow[t]{3}{*}{ CEP } & Industrials & 14 & 62.25 & 69.18 & 20.39 & 22.20 & 84.90 & -1.015 & 0.011 \\
\hline & Information Technology & 15 & 84.23 & 86.08 & 14.38 & 40.50 & 99.20 & -2.114 & 0.027 \\
\hline & Materials & 5 & 63.51 & 75.00 & 33.73 & 5.30 & 92.40 & -1.843 & 0.035 \\
\hline \multirow[t]{2}{*}{ CSP } & Consumer Discretionary & 11 & 83.62 & 88.73 & 12.72 & 53.80 & 95.10 & -1.723 & 0.004 \\
\hline & Industrials & 14 & 69.60 & 81.71 & 22.65 & 21.90 & 91.70 & -0.772 & 0.017 \\
\hline \multirow[t]{2}{*}{ ROE } & Consumer Discretionary & 11 & 41.90 & 38.51 & 21.23 & 18.94 & 89.45 & 1.459 & 0.013 \\
\hline & Utilities & 7 & 25.38 & 15.30 & 26.73 & 10.59 & 85.53 & 2.563 & 0.001 \\
\hline \multirow[t]{2}{*}{ ROIC } & Energy & 7 & -2.07 & 1.22 & 10.84 & -25.24 & 7.58 & -2.05 & 0.04 \\
\hline & Information Technology & 16 & 21.46 & 17.67 & 21.17 & -18.15 & 61.75 & 0.488 & 0.014 \\
\hline ROA & Energy & 7 & -1.70 & 0.97 & 9.09 & -21.18 & 6.22 & -2.076 & 0.042 \\
\hline \multirow[t]{5}{*}{ Profit } & Consumer Discretionary & 11 & 5.56 & 4.36 & 9.81 & -18.46 & 17.16 & -1.355 & 0.045 \\
\hline & Consumer Staples & 6 & 10.10 & 11.26 & 4.24 & 1.71 & 13.10 & -2.129 & 0.013 \\
\hline & Energy & 7 & -0.93 & 7.21 & 33.65 & -74.53 & 23.47 & -2.272 & 0.018 \\
\hline & Financials & 15 & 15.09 & 20.87 & 14.12 & -18.45 & 28.86 & -1.218 & 0.044 \\
\hline & Industrials & 14 & 12.70 & 8.92 & 14.36 & 0.98 & 47.96 & 1.93 & 0.003 \\
\hline Z-Score & Information Technology & 16 & 6.83 & 4.80 & 6.26 & 2.90 & 26.47 & 2.547 & 0.002 \\
\hline Q-Ratio & Information Technology & 16 & 3.03 & 2.28 & 1.72 & 1.29 & 7.46 & 1.681 & 0.004 \\
\hline
\end{tabular}

Note. Min. = minimum; Max. = maximum; CGP = corporate governance performance; CEP = corporate environmental performance; $\mathrm{CSP}=$ corporate social performance; $\mathrm{CSRO}=$ corporate social responsibility-overall; $\mathrm{ESG}=$ environmental, social, and governance criteria; $\mathrm{ROE}=$ return on equity; $\mathrm{ROIC}=$ return on investment capital; $\mathrm{ROA}=$ return on assets.

Descriptive statistics for all performance variables by industry are constant for Communication Services industry resulting in exclusion from the output. The output follows similar clustering patterns as Dataset A including a relatively flat distribution over all four years. The results of the Friedman Test used to determine changes in year over year performance, indicated statistically significant differences in CSRO, CGP, CSP and Q-Ratio from 2014 to 2015. A second significant difference for Q-Ratio occurred from 2016 to 2017.

Inspection of CSRO, CGP, CSP and Q-Ratio medians using the Wilcoxon Signed Rank Test shown medium effect sizes ( $r=0.38,0.35,0.35$, and 0.33 respectively) for the first set of differences and a small effect size $(r=0.26)$ for the second Q-Ratio difference. A Mann-Whitney U Test revealed significant differences in CSP of males and females for 2014 and 2015 with small effect sizes. Summaries in Table 6 and Table 7 present the results of the Wilcoxon and Mann-Whitney Tests for significant differences found. 
Table 6. Wilcoxon Signed-Rank Test (Friedman Test) Results

\begin{tabular}{lrrrrr} 
& $\begin{array}{c}2014 \\
\text { CS } 2015\end{array}$ & $\mathbf{2 0 1 4}$ to $\mathbf{2 0 1 5}$ & $\mathbf{2 0 1 4}$ to $\mathbf{2 0 1 5}$ & $\mathbf{2 0 1 4}$ to $\mathbf{2 0 1 5}$ & $\mathbf{2 0 1 6}$ to 2017 \\
Q-Ratio & CSP & Q-Ratio \\
\hline Z & -3.779 & -3.452 & -3.426 & -3.255 & -2.546 \\
Asymp. Sig. (2-tailed) & 0.000 & 0.001 & 0.001 & 0.001 & 0.011 \\
Md Oldest Year & 81.803 & 79.367 & 78.593 & 1.832 & 1.849 \\
Md Newest Year & 78.378 & 75.741 & 74.973 & 1.730 & 1.908 \\
Total Cases $(\mathrm{n})$ & 97 & 97 & 97 & 97 & 98 \\
\hline Effect Size $(\mathrm{r})$ & 0.38 & 0.35 & 0.35 & 0.33 & 0.26 \\
\hline
\end{tabular}

Note. Asymp. sig. = asymptotic significance; $\mathrm{CSRO}=$ corporate social responsibility-overall; CGP = corporate governance performance; $\mathrm{CSP}=$ corporate social performance.

Table 7. Mann-Whitney U Test (Friedman Test) Results

\begin{tabular}{|c|c|c|c|c|c|c|c|c|c|c|c|}
\hline & & \multicolumn{7}{|c|}{2014} & \multicolumn{3}{|c|}{2016} \\
\hline \multicolumn{2}{|c|}{ CEO Gender } & $\begin{array}{l}2014 \\
\text { CSRO }\end{array}$ & $\begin{array}{c}2104 \\
\text { CGP }\end{array}$ & $\begin{array}{c}2014 \\
\text { CSP }\end{array}$ & $\begin{array}{c}\text { Q- } \\
\text { Ratio }\end{array}$ & $\begin{array}{l}2015 \\
\text { CSRO }\end{array}$ & $\begin{array}{l}2105 \\
\text { CGP }\end{array}$ & $\begin{array}{c}2015 \\
\text { CSP }\end{array}$ & $\begin{array}{c}2015 \\
\text { Q-Ratio }\end{array}$ & $\begin{array}{c}\text { Q- } \\
\text { Ratio }\end{array}$ & $\begin{array}{c}2017 \\
\text { Q-Ratio }\end{array}$ \\
\hline \multirow[t]{2}{*}{ Male } & $n$ & 93 & 93 & 93 & 92 & 92 & 92 & 92 & 92 & 93 & 93 \\
\hline & Md & 80.77 & 79.79 & 77.58 & 1.80 & 77.78 & 75.74 & 74.15 & 1.71 & 1.74 & 1.91 \\
\hline \multirow[t]{2}{*}{ Female } & $n$ & 5 & 5 & 5 & 5 & 5 & 5 & 5 & 5 & 5 & 5 \\
\hline & Md & 97.03 & 84.62 & 93.18 & 2.39 & 80.65 & 87.90 & 93.26 & 2.31 & 2.53 & 2.27 \\
\hline \multicolumn{2}{|l|}{ Z } & -1.946 & -0.315 & -2.220 & -1.207 & -1.738 & -0.049 & -2.121 & -1.664 & -1.719 & -1.267 \\
\hline \multicolumn{2}{|l|}{ Sig. } & 0.052 & 0.753 & 0.026 & 0.227 & 0.082 & 0.961 & 0.034 & 0.096 & 0.086 & 0.205 \\
\hline \multicolumn{2}{|c|}{ Effect Size (r) } & 0.197 & 0.032 & 0.224 & 0.123 & 0.176 & 0.005 & 0.215 & 0.169 & 0.174 & 0.128 \\
\hline
\end{tabular}

A second Mann-Whitney test revealed significant differences between CEO genders in 2014 for CSP and again in 2015 for CSP and ROE. Although female medians were higher, the differences as presented in Table 8 were of small effect. The table also shows that male CEOs have higher medians than female for 2017 CGP, Profit, and Z-Score. The 2017 effect sizes $r=.045, r=.080$ and $r=.063$ are of small effect. A Kruskal-Wallis Test revealed significant differences between the four category groups for female C-Suite, male C-Suite and male Board of Directors. To provide a wholistic view of data, an analysis of the directional impact (positive and negative) of independent variables on dependent variables was performed (Table 9).

Table 8. Mann-Whitney U Test Results (CEO Gender)

\begin{tabular}{|c|c|c|c|c|c|c|c|}
\hline & & 2014 & 2015 & 2015 & 2017 & 2017 & 2017 \\
\hline \multicolumn{2}{|c|}{ CEO Gender } & CSP & CSP & ROE & CGP & Profit & Z-Score \\
\hline \multirow[t]{2}{*}{ Male } & $\mathrm{N}$ & 93 & 92 & 91 & 92 & 94 & 77 \\
\hline & Md & 77.58 & 74.15 & 21.38 & 80.10 & 9.58 & 3.87 \\
\hline \multirow[t]{2}{*}{ Female } & $\mathrm{N}$ & 5 & 5 & 5 & 5 & 5 & 5 \\
\hline & Md & 93.18 & 93.26 & 70.36 & 76.19 & 7.27 & 3.51 \\
\hline \multirow[t]{2}{*}{ Total } & $\mathrm{N}$ & 98 & 97 & 96 & 97 & 99 & 82 \\
\hline & Md & 78.59 & 75.56 & 21.86 & 78.87 & 9.55 & 3.85 \\
\hline \multicolumn{2}{|l|}{ Z } & -2.220 & -2.121 & -2.284 & -0.441 & -0.799 & -0.572 \\
\hline \multicolumn{2}{|c|}{ Asymp. Sig. (2-tailed) } & $0.026 *$ & $0.034 *$ & $0.022 *$ & 0.660 & 0.424 & 0.568 \\
\hline \multicolumn{2}{|c|}{ Effect Size (r) } & 0.224 & 0.215 & 0.233 & 0.045 & 0.080 & 0.063 \\
\hline
\end{tabular}

Note. Asymp. sig. = asymptotic significance; CSP = corporate social performance; ROE = return on equity;

CGP $=$ corporate governmental performance.

* There is a statistically significant difference in the group 
Table 9. Correlations of Directional Impact

\begin{tabular}{|c|c|c|c|c|c|c|c|c|c|c|c|}
\hline \multicolumn{6}{|c|}{ Positive Occurrences } & \multicolumn{6}{|c|}{ Negative Occurrences } \\
\hline Performance & $\mathrm{CEO}$ & $\begin{array}{c}\text { Female } \\
\text { board }\end{array}$ & $\begin{array}{l}\text { Male } \\
\text { board }\end{array}$ & $\begin{array}{l}\text { Women } \\
\text { C-suite }\end{array}$ & $\begin{array}{c}\text { Male } \\
\text { C-suite }\end{array}$ & Performance & $\mathrm{CEO}$ & $\begin{array}{c}\text { Female } \\
\text { board }\end{array}$ & $\begin{array}{l}\text { Male } \\
\text { board }\end{array}$ & $\begin{array}{l}\text { Women } \\
\text { C-suite }\end{array}$ & $\begin{array}{c}\text { Male } \\
\text { C-suite }\end{array}$ \\
\hline CSRO & 4 & 8 & 0 & 2 & 2 & CSRO & 0 & 0 & 8 & 6 & 6 \\
\hline CGP & 1 & 6 & 2 & 4 & 0 & CGP & 3 & 2 & 6 & 4 & 8 \\
\hline CEP & 4 & 7 & 2 & 3 & 4 & CEP & 0 & 1 & 6 & 5 & 4 \\
\hline CSP & 4 & 1 & 3 & 1 & 4 & CSP & 0 & 7 & 5 & 7 & 4 \\
\hline ROE & 4 & 5 & 1 & 8 & 0 & ROE & 0 & 3 & 7 & 0 & 8 \\
\hline ROIC & 4 & 3 & 2 & 8 & 0 & ROIC & 0 & 5 & 6 & 0 & 8 \\
\hline ROA & 4 & 0 & 4 & 7 & 0 & ROA & 0 & 8 & 4 & 1 & 8 \\
\hline Profit & 2 & 4 & 5 & 3 & 6 & Profit & 2 & 4 & 3 & 5 & 2 \\
\hline$z$ score & 0 & 8 & 0 & 7 & 4 & $z$ score & 4 & 0 & 8 & 1 & 4 \\
\hline$q$ ratio & 4 & 4 & 2 & 4 & 4 & $q$ ratio & 0 & 4 & 6 & 4 & 4 \\
\hline Total & 31 & 46 & 21 & 47 & 24 & Total & 9 & 34 & 59 & 33 & 56 \\
\hline
\end{tabular}

The values in Table 9 represent the number of positive and negative correlations as presented in the Spearman Rho correlations for all independent and dependent variables. The number presented does not consider the strength or weakness of the relationship. The results for CEO gender indicate that $84 \%$ of the 32 occurrences that took place between 2014 and 2017 are directionally positive for CSRO, ESG performance, and CFP. The total number of occurrences for board of director and Csuite increased to 64 , as it included both the percentage and the number of representations for male and female.

Female directors' impact is $53 \%$ positive, and female C-suite members' impact is $56 \%$ positive, thus outperforming their male counterparts (30\% and $25 \%$, respectively). CEO gender's positive impact on firm performance represented 50\% of the eight occurrences between 2014 and 2017 . The results for firm performance also show that female board of director impact is $75 \%$ and that the female Csuite impact is $69 \%$, thus outperforming their male peers (13\% and $50 \%$, respectively).

The correlation summary of significant relationships presented in Table 10 illustrates a positive relationship between the percentage representation of Female C-Suite, with ROE, ROIC, and ROA across all reporting years while Male C-Suite maintains a negative relationship. These results are consistent with the Kruskal-Wallis Test mentioned previously. One noteworthy result is the number of Female Board of Directors shows a positive relationship with CEO gender from 2014 to 2016. There are also positive relationships between the number of Female C-Suite, ROE, ROIC, and ROA with firm performance variables. 
Table 10. Correlation Summary (Bivariate)

\begin{tabular}{|c|c|c|c|c|c|c|c|}
\hline \multicolumn{4}{|c|}{ ESG, CSRO, and Financial performance } & \multicolumn{4}{|c|}{ Firm Performance } \\
\hline Variable & Year & Performance & Sig & Variable & Year & Performance & Sig \\
\hline & & & & \# Female C-Suite & 2014 & Z-Score & $.270^{*}$ \\
\hline \multirow[t]{3}{*}{ COE Gender } & 2015 & CSP & $.216^{*}$ & & 2015 & Z-Score & $.265^{*}$ \\
\hline & 2015 & ROE & $.234^{*}$ & & 2016 & Z-Score & $.235^{*}$ \\
\hline & & & & & 2017 & Z-Score & $.247^{*}$ \\
\hline \multirow[t]{6}{*}{ \# Female C-Suite } & 2016 & CEP & $-.225 *$ & & 2014 & ROE & $.602 * *$ \\
\hline & & & - & & & & \\
\hline & 2016 & CSP & $\begin{array}{c}.310^{* *} \\
-\end{array}$ & Q-Ratio & 2014 & ROIC & $.614^{* *}$ \\
\hline & 2016 & CSRO & $.274^{* *}$ & & 2014 & ROA & $.669 * *$ \\
\hline & 2017 & CSP & $-.237 *$ & & 2014 & Profit & $.241 *$ \\
\hline & 2017 & CSRO & $-.214^{*}$ & & 2015 & ROE & $.598 * *$ \\
\hline \multirow[t]{7}{*}{$\%$ Female C-Suite } & 2014 & ROE & $.267 * *$ & & 2015 & ROIC & $.628 * *$ \\
\hline & 2014 & ROIC & $.232 *$ & & 2015 & ROA & $.704 * *$ \\
\hline & 2014 & ROA & $.232 *$ & & 2015 & Profit & $.209 *$ \\
\hline & 2015 & ROE & $.236^{*}$ & & 2016 & ROE & $.587 * *$ \\
\hline & 2016 & ROIC & $.207^{*}$ & & 2016 & ROIC & $.604 * *$ \\
\hline & 2017 & ROE & $.311 * *$ & & 2016 & ROA & $.710 * *$ \\
\hline & 2017 & ROIC & $.217^{*}$ & & 2016 & Profit & $.227^{*}$ \\
\hline \multirow[t]{7}{*}{ \# Male C-Suite } & 2014 & ROE & $-.250 *$ & & 2017 & CEP & $.253^{*}$ \\
\hline & 2014 & ROIC & $-.230 *$ & & 2017 & CSP & $.213^{*}$ \\
\hline & 2014 & ROA & $-.237 *$ & & 2017 & CSRO & $.208^{*}$ \\
\hline & & & - & & & & \\
\hline & 2016 & ROE & $.274^{* *}$ & & 2017 & ROE & $.486 * *$ \\
\hline & 2016 & ROIC & $-.204 *$ & & 2017 & ROIC & $.564 * *$ \\
\hline & 2017 & ROE & $-.263 *$ & & 2017 & ROA & $.653^{* *}$ \\
\hline \multirow{11}{*}{$\%$ Male C-Suite } & & & - & & & & \\
\hline & 2014 & ROE & $.267 * *$ & & 2014 & CEP & $.235^{*}$ \\
\hline & 2014 & ROIC & $-.232 *$ & Z-Score & 2014 & ROE & $.379 * *$ \\
\hline & 2014 & ROA & $-.232 *$ & & 2014 & ROIC & $.633^{* *}$ \\
\hline & 2015 & ROE & $-.236 *$ & & 2014 & ROA & $.642^{* *}$ \\
\hline & & & - & & & & \\
\hline & 2016 & ROE & $.279 * *$ & & 2015 & CEP & $.242^{*}$ \\
\hline & 2016 & ROIC & $-.207 *$ & & 2015 & ROE & $.437 * *$ \\
\hline & & & - & & & & \\
\hline & 2017 & ROE & $.311^{* *}$ & & 2015 & ROIC & $.668^{* *}$ \\
\hline & 2017 & ROIC & $-.217^{*}$ & & 2015 & ROA & $.698 * *$ \\
\hline \multirow[t]{5}{*}{ \# Female Board } & 2014 & CEO & $.253^{*}$ & & 2015 & Profit & $.336 * *$ \\
\hline & 2015 & CEO & $.204 *$ & & 2016 & CEP & $.289 * *$ \\
\hline & 2016 & CEO & $.218^{*}$ & & 2016 & ROE & $.415^{* *}$ \\
\hline & & & & & 2016 & ROIC & $.660 * *$ \\
\hline & & & & & 2016 & ROA & $.691 * *$ \\
\hline \multirow[t]{3}{*}{$\%$ Female Board } & 2014 & Profit & $.238^{*}$ & & 2016 & Profit & $.385 * *$ \\
\hline & & & & & 2017 & CEP & $.267^{*}$ \\
\hline & & & & & 2017 & ROE & $.392 * *$ \\
\hline \multirow[t]{3}{*}{ \# Male Board } & 2016 & CGP & $-.203 *$ & & 2017 & ROIC & $.630 * *$ \\
\hline & 2016 & Q-Ratio & $-.217^{*}$ & & 2017 & ROA & $.656 * *$ \\
\hline & 2017 & ROIC & $-.202 *$ & & 2017 & Profit & $.280 *$ \\
\hline
\end{tabular}

Note. CSP = corporate social performance; CEP = corporate environmental performance; CGP = corporate governance performance; $\mathrm{CSRO}=$ corporate social responsibility-overall; $\mathrm{ROE}=$ return on equity; $\mathrm{ROIC}=$ return on investment capital; $\mathrm{ROA}=$ return on assets.

* Correlation is significant at the 0.05 level (2-tailed). ${ }^{* *}$ Correlation is significant at the 0.01 level (2-tailed). 
Figure 6 contains the number female C-Suite and female Board of Directors by industry for 2014 to 2017. The trends indicate the number of females increased for C-Suite and board of director positions across most industries. Real estate holds stagnant at eight female board members. Appendix B containing the average CSRO and ESG performance scores by industry indicates that Telecommunication, Information Technology, and Consumer Discretionary industries maintain the highest averaging scores for ESG performance and CSRO during the reporting period. Industrials, Consumer Staples and Consumer Discretionary industries maintain the highest averages for ROE, ROIC, and ROA. Real estate and financial industries report the highest averages in profit, while Consumer Staples tops out Tobin's Q and Z-score. Average performance scores separated by CEO gender show higher averages for female CEOs over male CEOs for several industries.
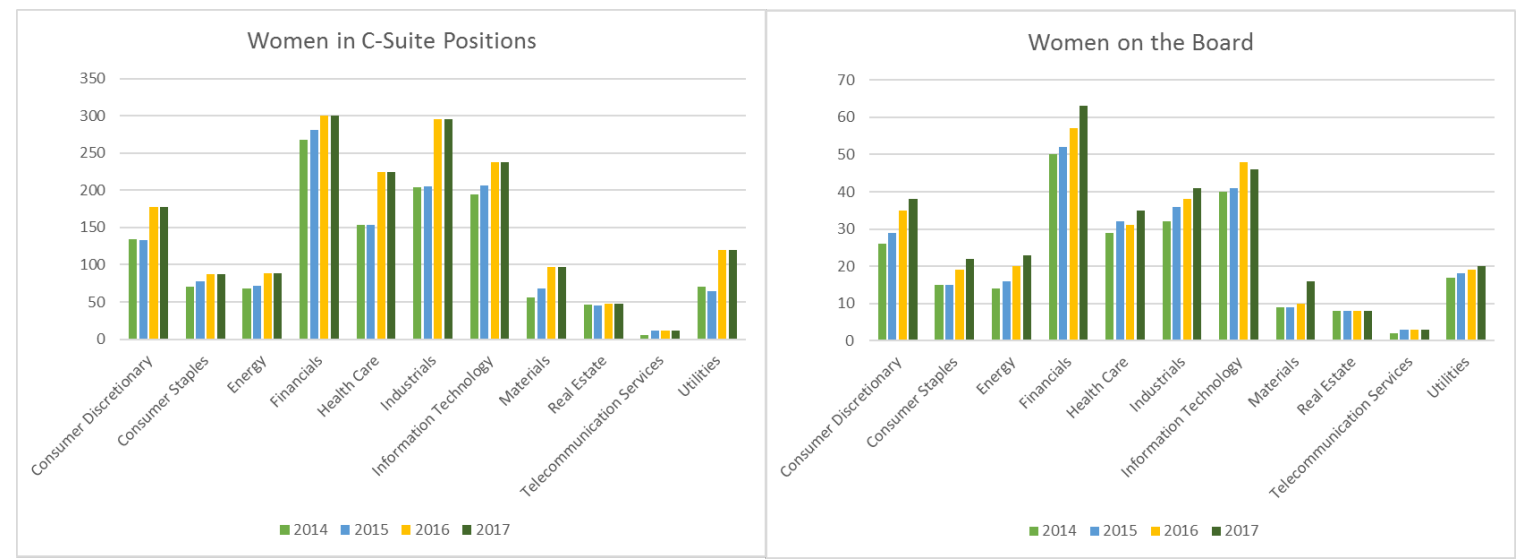

Figure 6. Female C-suite and board of director membership by industry, 2014 through 2017. Panel a) are the number of women $\mathrm{C}$-suite members in each year; b) are the number of women directors in each year.

\section{HYPOTHESES}

Hypothesis 1 states CEO gender has a positive impact on year over year corporate sustainability. The directional values in Table 9 indicates that CEOs created a positive impact $84 \%$ of the time across CSRO, ESG, and CFP. Of these occurrences, $11 \%$ are significant. . The correlation summary in Table 10 indicates that CEO gender had a significant positive relationship with CSP $(p=.216)$ and ROE $(\mathrm{p}=.234)$ in 2015. The null hypothesis is rejected, and the positive impact is con-firmed. Hypothesis 2 states Female CEOs have a higher positive impact than male CEOs on year over year corporate sustainability. The results of the Mann-Whitney Test indicate higher median $(\mathrm{Md})$ values for female CEOs in all years excluding 2017 CGP and Profit. Table 7 illustrates male CGP Md $=80.10$ compared to female CGP Md $=76.19$ and male Profit $\mathrm{Md}=9.58$ to female Profit $\mathrm{Md}=7.27$; each with small effect. The median differences between male and female scores are highlighted in Appendix B containing CEO gender comparison graphs for the shared industries; consumer staples, industrials, information technology, and utilities. The results show female CEOs produce a higher average than male CEO competitors for CSRO, CEP, CSP, CGP, ROE, ROIC, ROA and Profit for all years. Higher female averages are also shown for all industries except Consumer Staples, which indicate similar results for CGP. The null for this hypothesis is rejected.

Hypothesis 3 states that female C-suite presence has a positive impact on year-over-year corporate sustainability. The significant differences among the four categories found using the Kruskal-Wallis test produced incremental increases in ROE scores from 2014 to 2016. The correlation summary in Table 10 indicates significant positive relationships between the percentage of female C-suites with ROE and ROIC ( $\mathrm{p}=.207$ to .311) for all years. However, an inverse relationship exists between the number of female C-suites with CSRO ( $\mathrm{p}=-.214), \operatorname{CEP}(\mathrm{p}=-.225)$ and CSP $(\mathrm{p}=-.237)$ for 2016 and 2017. Although the correlation results are intriguing, the number of positive occurrences for all 
years is $56 \%$ (Table 9). Of these occurrences, $13 \%$ are significant. The null hypothesis is rejected, and the positive impact is confirmed.

Hypothesis 4 states female C-Suites have a higher positive impact than male C-Suites on year over year corporate sustainability. The directional values in Table 9 indicates that females' positive impact of $56 \%$ outweighed the males' positive impact of $25 \%$. None of these occurrences are significant. The null hypothesis is rejected, and a more positive impact is confirmed. Hypothesis 5 states female board member presence has a positive impact on year over year corporate sustainability. The directional values in Table 9 indicates that women on boards of directors yield a positive impact of $53 \%$. The correlation summary in Table 10 indicates significant positive relationships between the percentage of female board of directors and profit (significance $=.238^{*}$ ). The number of female board of directors did not yield any significant relationships with performance variables. The null hypothesis is rejected, and the positive impact is confirmed.

Hypothesis 6 female board member presence have a higher positive impact than male only board member presence on year over year corporate sustainability. The Kruskal-Wallis test did not present any findings on differences across the four category groups. The directional values in Table 9 indicates that females' positive impact of 53\% outweighs the males' positive impact of $30 \%$. The null hypothesis is rejected, and a more positive impact is confirmed.

Hypothesis 7 states there is a positive relationship between year over year firm performance and corporate sustainability. Correlations in Table 10 indicate positive relationships between Q-Ratio and ZScore across all years for CEP, ROE, ROIC, and ROA performance. The positive relationships represent $97 \%$ of relationships, of which $73 \%$ are significant (Table 9). The null hypothesis is rejected, and the positive relationship is confirmed.

\section{ADDITIONAL INSIGHT}

To gain additional insight on the effect of female presence, the Kruskal-Wallis Test was performed on the eight groups in Table 3 representing every combination of female leadership during 2014 to 2017. Results show female CEOs with greater than 33\% female board of director representation and less than or equal to $33 \%$ female C-Suite representation, produced significant changes in $2015 \mathrm{ROE}$ and ROIC. The directional values in Table 9 indicates that CEOs had a positive impact $50 \%$ of the time across the firm performance variables. Women on boards of directors had a positive impact $75 \%$ of the time, and women in C-suite positions did so $69 \%$ of the time. Both contributions outweighed those of their male peers for (boards of directors, 13\%; C-suites, $50 \%$ ) in the reporting period.

Appendix C contains the average CSRO and ESG performance scores by CEO gender and industry. CEO gender comparison graphs are limited to four shared industries between male and female leaders; consumer staples, industrials, information technology, and utilities. Results show that for female CEOs had higher impact than male CEOs in terms of year-over-year scores in $67 \%$ of occurrences. These additional findings are consistent with previous metrics and contribute to the overall discussion of sustainability.

To summarize, although this study's evidence shows that the gender of CEOs, C-suite members, and directors impacts corporate sustainability, these results are not consistent across all performance outcomes, industries, and time periods. To gain clarity, a holistic approach was applied by quantifying the positive occurrences for the entire reporting period and testing the hypotheses. The holistic results are shown in Table 11. The difference between female and male leaders' effectiveness is not large; however, this may be due to the small sample size. 
Table 11. Results for the Hypothesis Testing of Dataset B

\begin{tabular}{|c|c|c|c|}
\hline Hypothesis & Description & $\begin{array}{l}\text { Holistic View } \\
(\%)\end{array}$ & Results \\
\hline 1 & $\begin{array}{l}\text { CEO gender has a positive impact on year-over-year } \\
\text { corporate sustainability. }\end{array}$ & 84 & Supported \\
\hline 2 & $\begin{array}{l}\text { Female CEOs have a larger positive impact than male } \\
\text { CEOs on year-over-year corporate sustainability. }\end{array}$ & 67 & Supported \\
\hline 3 & $\begin{array}{l}\text { Female C-suite presence has a positive impact on } \\
\text { year-over-year corporate sustainability. }\end{array}$ & 56 & Supported \\
\hline 4 & $\begin{array}{l}\text { Female C-suites have a larger positive impact than } \\
\text { male C-Suites on year-over-year corporate sustainabil- } \\
\text { ity. }\end{array}$ & 56 & Supported \\
\hline 5 & $\begin{array}{l}\text { Female board member presence has a positive impact } \\
\text { on year-over-year corporate sustainability. }\end{array}$ & 53 & Supported \\
\hline 6 & $\begin{array}{l}\text { Female board member presence have a larger positive } \\
\text { impact than male only board member presence on } \\
\text { year-over-year corporate sustainability. }\end{array}$ & 53 & Supported \\
\hline 7 & $\begin{array}{l}\text { There is a positive relationship between year-over- } \\
\text { year firm performance and corporate sustainability. }\end{array}$ & 97 & Supported \\
\hline
\end{tabular}

\section{DISCUSSION AND CONCLUSION}

Sustainability leadership involves building trust and enforcing responsible interactions with people and the environment while also meeting stakeholder needs and promoting generational longevity (Elsaid, 2014; Glick, 2011; Idowu \& Louche, 2011). Corporate sustainability provides the checks and balances that are needed to measure the performance outcomes of the overarching CSR principles. The benefits of CSR include reduced operational costs and increased corporate value.

The purpose of the research is to determine corporate leadership gender impact on year over year corporate sustainability performance outcomes; financial performance, environmental performance, social performance, and governance performance over four years. Three research questions were presented to categorize impact based on CEO gender, C-suite gender, and board of director gender. To answer the research questions, seven hypotheses were examined using a qualitative methodology within the theoretical frameworks of Upper Echelon Theory and Social Role Theory.

Historical research of the Upper Echelon Theory suggests that corporate leaders' personal experience of right and wrong are determined by demographic and heterogenic influences (Nielsen, 2009). Historical research of the Social Role Theory suggests social training through the lens of gender stereotypes creates generalized expectations of right and wrong for ethics consideration (Weyer, 2007). Ultimately each theory influences business strategy and the prioritization of stake-holder needs. Leaders must gain a holistic understanding of stakeholder needs to successfully operate a business without sabotaging future generational needs (Shaw et al., 2012).

Scholars have suggested that communal behaviors and community-engagement activities can provide a corporation with a holistic understanding of stakeholder needs, in addition to building brand equity and trust (Green \& Cassell, 1996; Mattis, 1993). For instance, 20\% of female directors of Fortune 500 companies are actively engaged in their communities (Burke, 1993), and female leaders traditionally exhibit communal behaviors (Eagly, 1987; Weyer, 2007). The results of this study provide statistical evidence that, over a 4-year period, female CEOs produced better environmental, social, and governance performance than their male counterparts within the same industry. This implies that 
female leaders are more effective than male leaders in building trust, enforcing responsible interactions, and promoting generational longevity.

The review of literature presents a concise history of the evolution of sustainability from the inception of CSR in the early 19th century. Based on the proposed holistic view of sustainability, this study's literature review and empirical results support the legislative mandate of California Senate Bill 826 (Jackson, S., \& Atkins, S., 2018). by indicating that female leaders (CEOs, C-suite members, and directors) are beneficial to companies. This support extends previous contributions to leadership gender, sustainability, and business ethics. The Holistic Concentric Circles Model was introduced and provided directional analysis results to determine overall gender influence for the sample peri-od. As previously mentioned, evidence from historical literature and the results of this study, sup-port sustainability as an area of competitive advantage for women leaders.

Sustainability approaches continue to evolve as business models, strategies, processes, and reporting change to fit the needs of corporations and stakeholders. Organizations that are seeking to increase sustainability or financial performance, as well as those that seek to adopt the holistic concentric circles model, should thus include more female leaders on TMTs, as women are more likely than men to exhibit communal behaviors and bring active community engagement to corporate leader-ship positions. The researcher recommends generally conducting more studies in the area of corporate leadership gender and sustainability.

\section{REFERENCES}

Accenture. (2014). The UN Global Compact-Accenture CEO Study on Sustainability. Retrieved from www.accenture.com/institute

Adler, N. J. (1997). Global Leadership: Women Leaders. Management International Review, 37(1), 171-196.

Allouche, J. (Ed). (2006). Corporate social responsibility. Concepts, accountability and reporting. New York, NY: Palgrave Macmillan.

Arrow, K. J. (1985). Principals and agents: The structure of business. In J. W. Pratt \& R. J. Zeckhauser (Eds.), The economics of agency (pp. 37-51). Boston, MA: Harvard Business School Press.

Bear, S., Rahman, N., \& Post, C. (2010). The impact of board diversity and gender composition on corporate social responsibility and firm reputation. Journal of Business Ethics, 97, 207-221. https://doi.org/10.1007/s10551-010-0505-2

Bendell, J. (2009). The corporate responsibility movement. Sheffield, UK: Greenleaf Publishing Limited.

Bloomberg. (2018). The Company and Its Products. Retrieved from https://www.bloomberg.com

Borland, H. (2009). Conceptualizing global strategic sustainability and corporate transformational change. International Marketing Review, 26(4/5), 554-572. https://doi.org/10.1108/02651330910972039

Boulouta, I. (2012). Hidden connections: The link between board gender diversity and corporate social performance. Journal of Business Ethics, 113(2), 185-197. https://doi.org/10.1007/s10551-012-1293-7

Brockett, A. M., \& Rezaee, Z. (2012). Corporate sustainability. Hoboken, NJ: John Wiley \& Sons, Inc.

Brusseau, J. (2017). Three theories of corporate social responsibility. The business ethics workshop. Flat World Knowledge, L.L.C.

Burges, Z., \& Tharenou, P. (2002). Women board directors: Characteristics of the few. Journal of Business Ethics, $37(1), 39-49$.

Burke, R. J. (1993). Women on corporate boards of directors. Equal Opportunities International, 12(6), 5.

Carroll, A. B. (1979). A three-dimensional conceptual model of corporate performance. Academy of Management. The Academy of Management Review (pre-1986); 4(Oct), 497-505. https://doi.org/10.2307/257850

Carroll, A. B. (1991). The pyramid of corporate social responsibility: Toward the moral management of organizational stakeholders. Business Horizons, 34(4), 39-48. https://doi.org/10.1016/0007-6813(91)90005-g 
Carroll, A. B., Lipartito, K. J., Post, J. E., \& Werhane, P. H. (2012). Corporate responsibility: The American experience. Cambridge University Press.

Catalyst. (2016). Knowledge Center: Women CEOs of the S\&P 500. Retrieved from http://www.catalyst.org/knowledge/women-ceos-sp-500

Chen, C.-H. V. (2001). Androgyny and transformational leadership: Effects of gender and sex-role identity in the collectivistic context of Taiwan, R. O. C. Business. California, University of Southern California. Doctor of Philosophy: 192.

Clarkson_Centre_for_Business_Ethics (1999). Principles of Stakeholder Management: The Clarkson Principles. Toronto, Canada, Clarkson Centre for Business Ethics. https://doi.org/10.4135/9781412956260.n137

Crane, A., McWilliams, A., Matten, D., Moon, J., \& Siegel, D. S. (2008). Corporate Social Responsibility. Oxford University Press. https://doi.org/10.1093/oxfordhb/9780199211593.003.0001

Dahlsrud, A. (2008). How corporate social responsibility is defined: An analysis of 37 definitions. Corporate Social Responsibility and Environmental Management, 15(1), 1-13. https://doi.org/10.1002/csr.132

Daily, C. M., Dalton, D. R., \& Cannella, A. (2003). Corporate governance: Decades of dialogue and data. Academy of Management Journal, 28, 371-382. https://doi.org/10.2307/30040727

Doerre, S. (2001). Negotiating Gender and Authority in Northern Syria. International Negotiation, 6, 251-268. https://doi.org/10.1163/15718060120849062

Donaldson, T., \& Preston, L. E. (1995). The stakeholder theory of the corporation: concepts, evidence, and implications. Academy of Management, The Academy of Management Review, 20(1), 65-91. https://doi.org/10.2307/258887

Droll, S. (2013). Resource Dependency Theory and the Inclusion of Foreign Nationals on the Board of Directors of Publicly Traded Chilean Companies: A Multi-case Study. Dissertation, Georgia State University, https://scholarworks.gsu.edu/bus admin diss/21.

Eagly, A. H. (1987). Sex differences in social behavior: A social-role interpretation. Hillsdale, NJ: Erlbaum.

Eccles, R. G., Ioannou, I., \& Serafeim, G. (2014). The impact of corporate sustainability on organizational processes and performance. Management Science, 60(11), 2835-2857. https://doi.org/10.1287/mnsc.2014.1984

Elkington, J. (1997). Cannibals with forks: The triple bottom line of 21st century business. Oxford: Capstone.

Elsaid, E. (2014). Examining the effect of change in CEO gender, functional and educational background on firm performance and risk. The Journal of Applied Business Research, 30(6), 1605-1614. https://doi.org/10.19030/jabr.v30i6.8878

Environmental_Protection_Agency. (2011). Environmental management system glossary. Retrieved from https://iaspub.epa.gov/sor internet/registry/termreg/searchandretrieve/glossariesandkeywordlists/searc h.do?details $=\&$ vocabName $=$ EMS $\% 20$ Glossary

Feng, M., Wang, X., \& Kreuze, J. G. (2017). Corporate social responsibility and firm financial performance. American Journal of Business, 32(3/4), 106-133. https://doi.org/10.1108/ajb-05-2016-0015

Freeman, E., \& Dmytriyev, S. (2017). Corporate social responsibility and stakeholder theory: Learning from each other. SYMPHONYA Emerging Issues in Management, 2, 7-15.

Friedman, M. (1970). The social responsibility of businesses to increase its profits. New York. Times Magazine, 32$33,122,126$.

Gao, J. (2008). The evolution of business sustainability: Historical trajectory and structural relationships. School of Graduate and Postdoctoral Studies. Library and Archives Canada, The University of Western Ontario. Doctor of Philosophy: 185.

Geva, A. (2008). Three models of corporate social responsibility: Interrelationships between theory, research, and practice. Business and Society Review, 113(1), 41. https://doi.org/10.1111/j.1467-8594.2008.00311.x 
Glass, C., Cook, A., \& Ingersoll, A. R. (2016). Do women leaders promote sustainability? Analyzing the effect of corporate governance composition on environmental performance. Business Strategy and the Environment, 25(7), 495-511. https://doi.org/10.1002/bse.1879

Glick, M. B. (2011). The role of chief executive officer. School of Education. Fort Collins, Colorado, Colorado State University. Doctor of Philosophy.

Green, E., \& Cassell, C. M. (1996). Women managers. Gendered cultural processes and organizational change. Gender, Work, and Organizational, 3(3). https://doi.org/10.1111/j.1468-0432.1996.tb00057.x

Hale, J. (2016) How Sustainalytics Does Company ESG. Retrieved from Yahoo! Finance website: https://finance.yahoo.com/news/sustainalytics-does-company-esg-research-100000652.html

Hambrick, D. C. (2007). Upper echelons theory: An update. Academy of Management Review, 32(2), 334-343. https://doi.org/10.5465/amr.2007.24345254

Hambrick, D. C., \& Mason, P. A. (1984). Upper echelons: The organization as a reflection of its top managers. The Academy of Management Review, 9(2), 193-206. https://doi.org/10.5465/amr.1984.4277628

Hammer, J. (2015). When three equals one. Economic Development Journal, 14(3), 5-10.

Heald, M. (1970). The social responsibilities of business: Company and community, 1900-1960. Cleveland, OH: The Press of Case Western Reserve University. https://doi.org/10.1086/ahr/76.5.1615-a

Henriques, A., \& Richardson, J. (2004). The Triple Bottom, Line does it all add up? Sterline, VA: Earthscan.

Hernandez Bark, A. S., Escartín, J., Schuh, S. C., \& van Dick, R. (2015). Who leads more and why? A mediation model from gender to leadership role occupancy. Journal of Business Ethics, 139(3), 473-483. https://doi.org/10.1007/s10551-015-2642-0

Herriott, S. R. (2016). Metrics for sustainable business. New York, NY, Routlege.

Hillman A, Cannella, Jr., A., \& Harris, I. C. (2002). Women and racial minorities in the boardroom: how do directors differ? Journal of Management, 28, 747-763. https://doi.org/10.1177/014920630202800603

Ho, S. S. M., Li, A. Y., Tam, K., \& Zhang, F. (2014). CEO Gender, Ethical Leadership, and Accounting Conservatism. Journal of Business Ethics, 127(2), 351-370. https://doi.org/10.1007/s10551-013-2044-0

Hoffman, M. L. (2013). The impact of gender on global leadership effectiveness: Building a model for female global leaders. School of Business and Technology. ProQuest LLC, Capella University. Doctor of Philosophy: 201.

Huse, M., Nielsen, S. T., \& Hagen, I. M (2009). Women and employee-elected board members, and their contributions to board control tasks. Journal of Business Ethics, 89, 581-597. https://doi.org/10.1007/s10551008-0018-4

Hutchings, K., Metcalfe, B. D., \& Cooper, B. K. (2010). Exploring Arab Middle Eastern women's perceptions of barriers to and facilitators of international management opportunities. The International Journal of Human Resources Management, 21(1), 61-83. https://doi.org/10.1080/09585190903466863

Ibrahim, N. A., \& Angelidis, J. P. (1994). Effect of board members' gender on corporate social responsiveness orientation. Journal of Applied Business Research, 10, 35-43. https://doi.org/10.19030/jabr.v10i1.5961

Idowu, S. O., \& Louche (Eds.). (2011). Theory and practice of corporate social responsibility. Verlang Berlin Heidelberg: Springer.

IFAC. (2003). Enterprise governance: Getting the balance right. Retrieved from http://www.ifac.org/system/files/downloads/Enterprise Governance.pdf

Jalbert, T., Jalbert, M., \& Furumo, K. (2013). The Relationship Between CEO Gender, Financial Performance, And Financial Management. Journal of Business \& Economics Research, 11(1), 25-34. https://doi.org/10.19030/jber.v11i1.7520

Jackson, S., \& Atkins, S. (2018). SB 826, Jackson. Corporations: boards of directors. Senate. California, Legislative Counsel's Digest.

Javidan, M., Bullough, A., \& Dibble, R. (2016). Mind the gap: Gender differences in global leadership selfefficacies. Academy of Management Perspectives, 30(1), 59-73. https://doi.org/10.5465/amp.2015.0035 
Jeong, S.-H., \& Harrison, D. A. (2017). Glass breaking, strategy making, and value creating: Meta-analytic outcomes of women as CEOs and TMT members. Academy of Management Journal, 60(4), 1219-1252. https://doi.org/10.5465/amj.2014.0716

Jeurissen, R. (2000). Cannibals with forks: The triple bottom line of 21 st century business. Journal of Business Ethics, 23(2).

Kapoor, C. (2011). Defining diversity: the evolution of diversity. Worldwide Hospitality and Tourism Themes, 3(4), 284-293. https://doi.org/10.1108/17554211111162408

Karlson, K. (2016). 29 popular financial KPIs for your financial KPI dashboard. Retrieved from https://www.scoro.com/blog/financial-kpis-for-financial-kpi-dashboard/

Khan, W. A., \& Vieito, J. P. (2013). CEO gender and firm performance. Journal of Economics and Business, 67, 5566. https://doi.org/10.1016/i.jeconbus.2013.01.003

Kim, D., \& Starks, L. T. (2016). Gender diversity on corporate boards: Do women contribute unique skills? American Economic Review, 106(5), 267-271. https://doi.org/10.1257/aer.p20161032

Kiser, A. I. T. (2015). Workplace and leadership perceptions between men and women. Gender in Management: An International Journal of Bank Marketing, 30(8), 598-612. https://doi.org/10.1108/gm-11-2014-0097

Klettner, A., Clarke, T., \& Boersma, M. (2014). The governance of corporate sustainability: Empirical insights into the development, leadership and implementation of responsible business strategy. Journal of Business Ethics, 122, 145-165. https://doi.org/10.1007/s10551-013-1750-y

Koenig, A. M., \& Eagly, A. H. (2014). Evidence for the social role theory of stereotype content: Observations of groups' roles shape stereotypes. Journal of Personality and Social Psychology, 107(3), 371-392. https://doi.org/10.1037/a0037215

Konadu, R. (2017). Gender diversity impact on corporate social responsibility (CSR) and greenhouse gas emissions in the UK. Economics and Business Review, 3(1), 127-148. https://doi.org/10.18559/ebr.2017.1.7

Kotler, P., \& Lee, N. (2005). Corporate social responsibility: Doing the most good for your company and your cause. Hoboken, NJ: John Wiley \& Sons, Inc. https://doi.org/10.5465/amp.2006.20591016

KPMG. (2018). ESG, risk, and return: A board's eye view. Audit Committee Institute.

Lamsa, A.-M., Sakkinen, A., \& Turjanmaa, P. (2000). Values and their change during the business education-A gender perspective. International Journal of Value-Based Management, 13(3), 203-213. https://doi.org/10.1023/a:1007884005732

Mackey, J. B. (2005). International corporate social responsibility: Assessing U.S.-based multinationals' location and globalization of operations. P. S. University. Ann Arbor, Ml, ProQuest Information and Learning Company: 171.

Marshall, J., \& Hopfl, H. (2007). The gendering of leadership in corporate social responsibility. Journal of Organizational Change Management, 20(2), 165-181. https://doi.org/10.1108/09534810710724739

Mattis, M. C. (1993). Women directors: Progress and opportunities for the future. Business and the Contemporary World, 5.

McWilliams, A., Siegel, D. S., \& Wright, P. M (2006). Corporate social responsibility: Strategic implications. Journal of Management Studies, 43(1), 1-18.

Medland, D. (2015). Managing 'stakeholder interaction' for better business strategy. Forbes.

Moreno-Gómez, J., Lafuente, E., \& Vaillant, Y. (2018). Gender diversity in the board, women's leadership and business performance. Gender in Management: An International Journal, 33(2), 104-122. https://doi.org/10.1108/gm-05-2017-0058

Muja, N., Appelbaum, S. H., Walker, T., Ramadan, S., \& Sodeyi, T. (2014). Sustainability and organizational transformation: putting the cart before the horse? (part one). Industrial and Commercial Training, 46(5), 249256. https://doi.org/10.1108/ict-02-2013-0007

Müller, A.-L., \& Pfleger. R. (2014). Business transformation towards sustainability. Business Research, 7(2), 313 350. 
Nielsen, S. (2009). Top management team diversity: A review of theories and methodologies. International Journal of Management Reviews.

Nielsen, S., \& Huse, M (2010). The contribution of women on boards of directors: Going beyond the surface. Corporate Governance: An International Review, 18(2), 136-148. https://doi.org/10.1111/i.1467$\underline{8683.2010 .00784 . x}$

Pallant, J. (2016). SPSS survival manual: A step by step guide to data analysis using IBM SPSS. New York, NY: Open University Press. https://doi.org/10.1111/1753-6405.12166

Poolthong, Y., \&. Mandhachitara, R. (2009). Customer expectations of CSR, perceived service quality and brand effect in Thai retail banking. International Journal of Bank Marketing, 27(6), 408-427. https://doi.org/10.1108/02652320910988302

Post, C., \&. Byron, K. (2015). Women on boards and firm financial performance: A meta-analysis. Academy of Management Journal, 58(5), 1546-1571. https://doi.org/10.5465/amj.2013.0319

Rahman, S. (2011). Evaluation of definitions: Ten dimensions of corporate social responsibility. World Review of Business Research, 1(1), 166-176.

Rezaee, Z. (2016). Business sustainability research: A theoretical and integrated perspective. Journal of Accounting Literature, 36, 48-64. https://doi.org/10.1016/j.acclit.2016.05.003

Ribera, K. C. F. (2010). Corporate social responsibility practices and financial performance over time for selected U.S. corporations. Office of Graduate Studies. ProQuest LLC., Texas A\&M University. Doctor of Philosophy: 1543.

RobecoSAM. (2016). CS A guide - RobecoS AM's corporate sustainability assessment methodology. Switzerland.

Roberts, D. (2017). Gender and Ethnic Diversity in US Boardrooms: Is the Glass Ceiling Stifling Firm Financial Growth? Dissertation, Georgia State University, https://scholarworks.gsu.edu/bus admin diss/82.

Ryan, M. K., \& Haslam, S. A. (2007). The glass cliff: Exploring the dynamics surrounding the appointment of women to precarious leadership positions. Academy of Management Review, 32(2), 549-572. https://doi.org/10.5465/amr.2007.24351856

S\&P_Dow_Jones_Indices (2018). Our company. Retrieved from https://us.spindices.com/

Schein, V. E., Muller, R., Lituchy, T., \& Liu, J. (1996). Think manager-think male: A global phenomenon? Journal of Organizational Behavior, 17, 33-41. https://doi.org/10.1002/(sici)1099-1379(199601)17:1<33::aidjob778>3.0.co;2-f

Shaw, L. C., Nemer, J., Vial, M., \& Garner, E. (Eds.) (2012). SAGE brief guide to corporate social responsibility. Los Angeles, SAGE Publications, Ltd.

Singh V, Terjesen S, \& Vinnicombe, S. (2008). New appointed directors in the boardroom: How do women and men differ? European Management Journal, 26, 48-58. https://doi.org/10.1016/j.emj.2007.10.002

Smith, C., \& Watts. R. (1992). The investment opportunity set and corporate financing, dividend and compensation policies. Journal of Financial Economics, 32, 263-292. https://doi.org/10.1016/0304-405x(92)90029-w

Srichatsuwan, S. (2014). Corporate social responsibility and performance: A study of small businesses in the United States. A. I. University. San Diego, CA.

Sustainalytics. (2018). History of sustainalytics. Retrieved from https://www.sustainalytics.com/

Szwajkowski, E. (2000). Simplifying the principles of stakeholder management: The three most important principles. Business \& Society, 39(4), 379-396. https://doi.org/10.1177/000765030003900403

Tay, S. (2019). CEO: Companies have a fiscal responsibility to push women in leadership. Retrieved from https://www.cnbc.com/2019/03/08/ceo-companies-have-responsibility-to-push-for-more-womenleaders.html

Vanderbroeck, P. (2010). The traps that keep women from reaching the top and how to avoid them. Journal of Management Development, 29(9), 764-770.

doi:10.1108/02621711011072478https://doi.org/10.1108/02621711011072478 
Corporate Sustainability: Corporate Leadership Impact

Velte, P. (2016). Women on management board and ESG performance. Journal of Global Responsibility, 7(1), 98109. https://doi.org/10.1108/igr-01-2016-0001

Wang, X. (2015). Corporate social responsibility v.s. basic corporate responsibility: Sustainability reporting of Chinese listed agribusinesses. International OFEL Conference on Governance, 297-312.

WCED. (1987). Our common future. Oxford, UK: Oxford University Press.

Weyer, B. (2007). Twenty years later: Explaining the persistence of the glass ceiling for women leaders. Women in Management Review, 22(6), 482-496. https://doi.org/10.1108/09649420710778718

Whalen, R. M. (2013). Corporate social responsibility and its relationship with financial performance. C. University. ProQuest LLC.: 133.

Wu, Q., He, Q., \& Duan, Y. (2013). Explicating dynamic capabilities for corporate sustainability. EuroMed Journal of Business, 8(3), 255-272. https://doi.org/10.1108/emjb-05-2013-0025 


\section{APPENDIX A}

\section{SUSTAINABILITY PERFORMANCE KPIS (EXAMPLES)}

\begin{tabular}{|c|c|c|c|}
\hline \multicolumn{4}{|c|}{ Corporate Governance Performance } \\
\hline \multicolumn{2}{|c|}{ Oversight Function } & \multicolumn{2}{|c|}{ Managerial Function } \\
\hline 1 & Number of board committees & 1 & Risk management \\
\hline 2 & Percentage of board independence & 2 & Codes of conduct and ethics \\
\hline 3 & Full independence of board committees & 3 & Executive compensation \\
\hline 4 & $\begin{array}{l}\text { Board diversity in terms of ethnicity, sex, } \\
\text { expertise, etc. }\end{array}$ & 4 & Stock-based compensation \\
\hline 5 & Staggered board & 5 & Dividend policy \\
\hline \multicolumn{2}{|c|}{ Compliance Function } & \multicolumn{2}{|c|}{ Internal Audit Function } \\
\hline 1 & Existence of compliance board committee & 1 & $\begin{array}{l}\text { Existence of internal audit } \\
\text { function }\end{array}$ \\
\hline 2 & Executive compliance officer & 2 & $\begin{array}{l}\text { Audit committee oversight of } \\
\text { internal audit department }\end{array}$ \\
\hline 3 & $\begin{array}{l}\text { Number of instances of noncompliance } \\
\text { with applicable rules, laws, regulations, } \\
\text { and standards }\end{array}$ & 3 & $\begin{array}{l}\text { Independence of internal audit } \\
\text { function }\end{array}$ \\
\hline 4 & $\begin{array}{l}\text { Cost of compliance with applicable rules, } \\
\text { laws, regulations, and standards }\end{array}$ & 4 & $\begin{array}{l}\text { Appointment of the chief audit } \\
\text { executive (CAE) by the audit } \\
\text { committee }\end{array}$ \\
\hline 5 & $\begin{array}{l}\text { Whistle-blowing policies, programs, and } \\
\text { procedures }\end{array}$ & 5 & $\begin{array}{l}\text { Internal audit reports to audit } \\
\text { committee }\end{array}$ \\
\hline
\end{tabular}

\section{External Audit Function}

\section{Legal and Financial Advisors} Function

\begin{tabular}{|l|l|r|l|}
\hline 1 & The ratio of non-audit fee to total audit fee & 1 & $\begin{array}{l}\text { Existence of in-house legal } \\
\text { counsel }\end{array}$ \\
\hline 2 & Audit quality & 2 & Quality of legal services \\
\hline 3 & Auditor independence & 3 & Analyst followings \\
\hline 4 & PCAOB inspection reports & 4 & Analyst forecast dispersion \\
\hline 5 & $\begin{array}{l}\text { Compliance with professional auditing, } \\
\text { ethics, and quality-control standards }\end{array}$ & 5 & Analyst forecast accuracy \\
\hline 1 & Say-on-pay & 1 & $\begin{array}{l}\text { Donations and other social } \\
\text { expenses }\end{array}$ \\
\hline 2 & Majority voting system & 2 & $\begin{array}{l}\text { Description of social and other } \\
\text { activities and projects }\end{array}$ \\
\hline 3 & Shareholders' democracy & 3 & $\begin{array}{l}\text { Diversity and equal } \\
\text { opportunities }\end{array}$ \\
\hline 4 & Institutional investors' ownership & $4 \begin{array}{l}\text { Fair wages, contracts and } \\
\text { benefits for employees }\end{array}$ \\
\hline 5 & Poison pills & 5 & $\begin{array}{l}\text { Training and internal } \\
\text { continuing education }\end{array}$ \\
\hline
\end{tabular}

Note. Adapted from Corporate Sustainability, by A. M. Brockett and Z. Rezaee, 2012, Hoboken, NJ, John Wiley \& Sons, pp. 135-137, 176. Copyright 2013 by John Wiley \& Sons - Books. Adapted with permission. 


\begin{tabular}{|l|l|l|l|}
\hline \multicolumn{2}{|c|}{ Corporate Environmental Performance } \\
\hline 1 & $\begin{array}{l}\text { Continuous replacement of nonrenewable } \\
\text { and scarce resources }\end{array}$ & $5 \begin{array}{l}\text { Disclosure of risk exposure } \\
\text { and opportunities for climate } \\
\text { change }\end{array}$ \\
\hline 2 & Disclosure of ecosys tem changes & 6 & $\begin{array}{l}\text { Disclosure of toxic chemical } \\
\text { use and disposal }\end{array}$ \\
\hline 3 & $\begin{array}{l}\text { Disclosure of gigajoules of total energy } \\
\text { consumed }\end{array}$ & $7 \begin{array}{l}\text { Efficient utilization of } \\
\text { unconventional renewable and } \\
\text { nonrenewable nature } \\
\text { resources }\end{array}$ \\
\hline 4 & $\begin{array}{l}\text { Disclosure of metric tons of total carbon } \\
\text { dioxide (C02) emitted }\end{array}$ & $8 \begin{array}{l}\text { Efficient use of recycled } \\
\text { materials }\end{array}$ \\
\hline
\end{tabular}

Note. Adapted from Corporate Sustainability, by A. M. Brockett and Z. Rezaee, 2012, Hoboken, NJ, John Wiley \& Sons, p. 197. Copyright 2013 by John Wiley \& Sons - Books. Adapted with permission.

\begin{tabular}{|c|c|c|c|}
\hline \multicolumn{4}{|c|}{ Corporate Social Performance } \\
\hline 1 & $\begin{array}{l}\text { A reliable social net for the low-income } \\
\text { households }\end{array}$ & 5 & $\begin{array}{l}\text { Company's total number of } \\
\text { injuries and fatalities, including } \\
\text { no-lost-time injuries per one } \\
\text { million hours worked }\end{array}$ \\
\hline 2 & Access to appropriate health care & 6 & $\begin{array}{l}\text { Customer satisfaction, } \\
\text { retention, and loyalty }\end{array}$ \\
\hline 3 & Access to education & 7 & $\begin{array}{l}\text { Description of social and ethic } \\
\text { activities and projects }\end{array}$ \\
\hline 4 & Access to information exchange & 8 & $\begin{array}{l}\text { Diversity and equal } \\
\text { opportunities }\end{array}$ \\
\hline
\end{tabular}

Note. Adapted from Corporate Sustainability, by A. M. Brockett and Z. Rezaee, 2012, Hoboken, NJ, John Wiley \& Sons, p. 151. Copyright 2013 by John Wiley \& Sons - Books. Adapted with permission.

\begin{tabular}{|c|c|c|c|}
\hline \multicolumn{4}{|c|}{ Corporate Financial Performance } \\
\hline \multicolumn{2}{|c|}{ Financial } & \multirow[b]{2}{*}{5} & \multirow[b]{2}{*}{ Net Profit Margin } \\
\hline 1 & Operating Cash Flow (OCF) & & \\
\hline 2 & Current Ratio & 6 & Gross Profit Margin \\
\hline 3 & Quick Ratio/Acid Test & 7 & Working Capital \\
\hline 4 & Burn Rate & 8 & Current Accounts Receivable \\
\hline
\end{tabular}

Note: Adapted from "29 Popular Financial KPIs for Your Financial KPI Dashboard," by K. Karlson, Scoro, 2016, https://www.scoro.com/blog/financial-kpis-for-financial-kpi-dashboard. Copyright 2019 by Scoro Software.

Adapted with permission. 


\section{APPENDIX B}

\section{AVERAGE SCORES BY INDUSTRY}

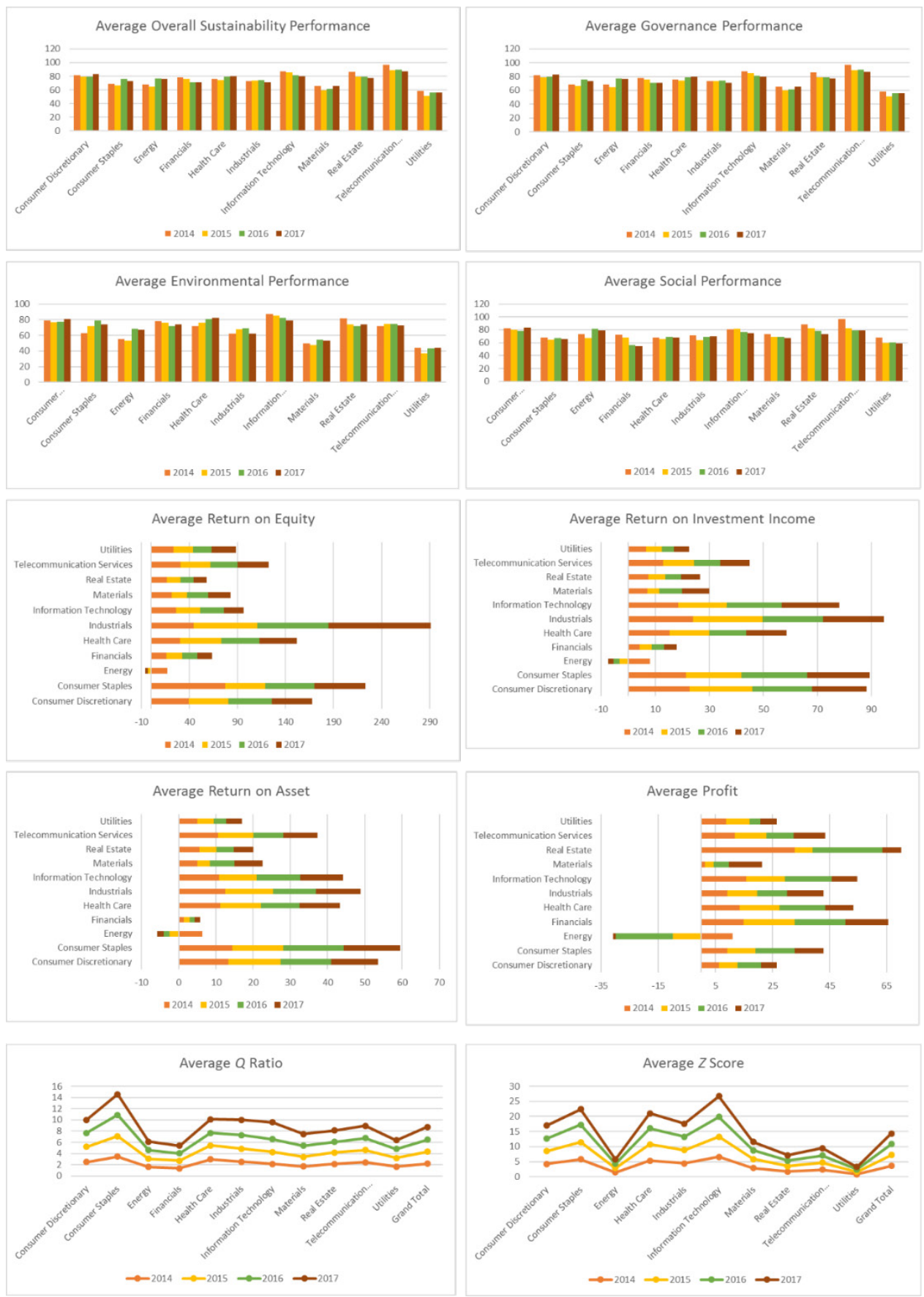

Figure B1. The list of panels represents the average scores for CSRO, ESG, CFP, and firm performance by industry, 2014 through 2017. Panel a) are the CSRO averages in each year; b) are the CGP averages in each year. c) are the CEP averages in each year. d) are the CSP averages in each year. e) are the ROE averages in each year. $f$ ) are the ROI averages in each year. $g$ ) are the ROA averages in each year. $h$ ) are the profit averages in each year. i) are the $q$ ratio averages in each year. $j$ ) are the $z$ score averages in each year. 


\section{APPENDIX C}

\section{AVERAGE SCORES BY CEO GENDER AND INDUSTRY}

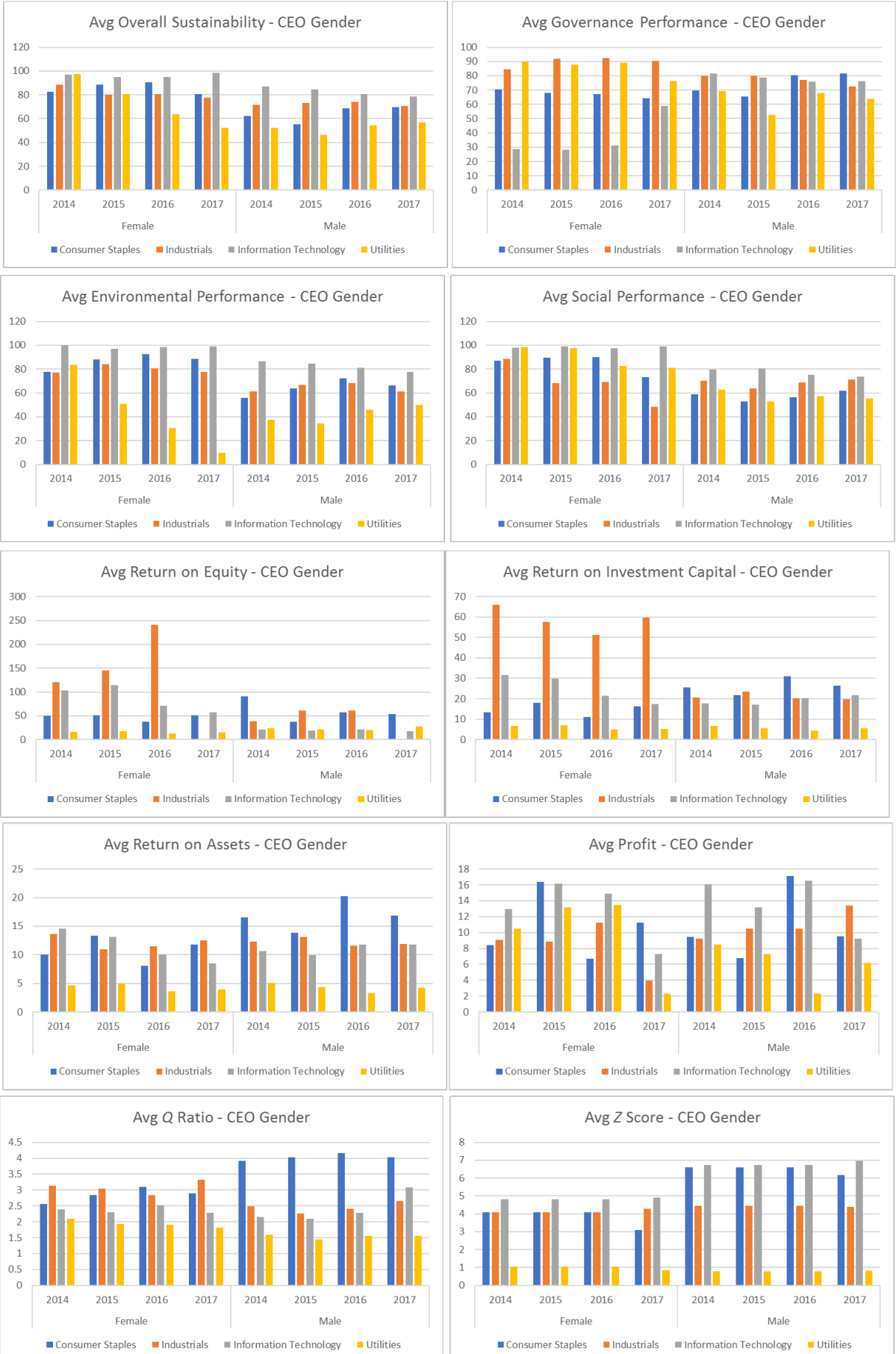

Figure C1. The list of panels represents the average scores for CSRO, ESG, CFP, and firm performance by gender and industry, 2014 through 2017. There are only four industries containing male and female CEOs. Panel a) are the CSRO averages in each year; b) are the CGP averages in each year. c) are the CEP averages in each year. d) are the CSP averages in each year. e) are the ROE averages in each year. $f$ ) are the ROI averages in each year. $g$ ) are the ROA averages in each year. $h$ ) are the profit averages in each year. i) are the $q$ ratio averages in each year. j) are the $z$ score averages in each year. 


\section{BIOGRAPHY}

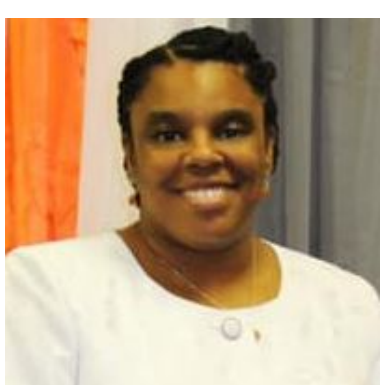

Dr. Jennoa R. Graham is an Executive Consultant with over 18 years industry experience providing financial and operational process excellence. She is an international speaker, author, and the occasional trumpet player. She is also a dedicated and active member of Heavens Harvest Ministries (HHM) Worship Center and Rotary International Club. As a 3rd year doctoral student at Georgia State University who has successfully defended her proposal, she is looking forward to graduating and continuing to serve communities and businesses in excellence. 